OPEN ACCESS

Edited by:

Barbara Mauz,

University of Salzburg, Austria

Reviewed by:

Aggeliki Georgiopoulou,

University of Brighton,

United Kingdom

Nicholas Perez,

Texas A\&M University, United States

*Correspondence: Andy R. Emery ee06ae@leeds.ac.uk

Specialty section: This article was submitted to Sedimentology, Stratigraphy and Diagenesis,

a section of the journal

Frontiers in Earth Science

Received: 03 June 2019

Accepted: 27 August 2019

Published: 12 September 2019

Citation:

Emery AR, Hodgson DM,

Barlow NLM, Carrivick JL, Cotterill CJ

and Phillips E (2019) Left High

and Dry: Deglaciation of Dogger

Bank, North Sea, Recorded

in Proglacial Lake Evolution.

Front. Earth Sci. 7:234.

doi: 10.3389/feart.2019.00234

\section{Left High and Dry: Deglaciation of Dogger Bank, North Sea, Recorded in Proglacial Lake Evolution}

\author{
Andy R. Emery ${ }^{1 *}$, David M. Hodgson ${ }^{1}$, Natasha L. M. Barlow ${ }^{1}$, Jonathan L. Carrivick, \\ Carol J. Cotterill ${ }^{3}$ and Emrys Phillips ${ }^{3}$
}

${ }^{1}$ School of Earth and Environment, University of Leeds, Leeds, United Kingdom, ${ }^{2}$ School of Geography, University of Leeds, Leeds, United Kingdom, ${ }^{3}$ British Geological Survey, The Lyell Centre, Edinburgh, United Kingdom

Reconstructions of palaeo-ice sheet retreat in response to climate warming using offshore archives can provide vital analogs for future ice-sheet behavior. At the Last Glacial Maximum, Dogger Bank, in the southern North Sea, was covered by the Eurasian Ice Sheet. However, the maximum extent and behavior of the ice sheet in the North Sea basin is poorly constrained. We reveal ice-marginal dynamics and maximum ice extent at Dogger Bank through sedimentological and stratigraphic investigation of glacial and proglacial lake sediments. We use a large, integrated subsurface dataset of shallow seismic reflection and geotechnical data collected during windfarm site investigation. For the first time, an ice stream is identified at Dogger Bank, based on preserved subglacial bedforms, eskers and meltwater channels. During ice-sheet advance, a terminal thrustblock moraine complex formed, whose crest runs approximately north-northeast to south-southwest. Subsequent ice stream shutdown caused stagnation of ice, and rapid retreat of the ice-sheet margin. The moraine complex, and outwash head from an adjacent ice-sheet lobe to the west, dammed a large (approximately $750 \mathrm{~km}^{2}$ ) proglacial lake. Subsequent sedimentation infilled the lake with $30 \mathrm{~m}$ of glacial outwash sediments. A lobate subaqueous fan formed at the ice-sheet margin, which thins toward the southeast with iceberg scours and ice-rafted debris at the base, and is onlapped by lake sediments calibrated to core as alternating clay and silt laminae, interpreted to be varves. The lake became isolated from the retreating ice-sheet margin, and ice-sheet retreat slowed. Sediment-laden meltwater was supplied to the ice-distal proglacial lake for c. 1500-2000 years. Subsequent ice-sheet retreat off Dogger Bank was more rapid due to the negative subglacial slope. The stepped retreat of rapid downwasting, slow retreat, and a final rapid phase off Dogger Bank occurred after the LGM at around $27 \mathrm{ka}$ and before formation of a ribbon lake, dated previously to $23 \mathrm{ka}$ and approximately $60 \mathrm{~m}$ lower in elevation, formed to the north of Dogger Bank. The complicated stratigraphic architecture revealed through these data improves forecasting of ground conditions for turbine footings at Dogger Bank, an important step in the provision of clean, sustainable energy.

Keywords: North Sea, ice stream, proglacial lake, British-Irish Ice Sheet, glacial geomorphology, glacial stratigraphy, shallow seismic, Quaternary 


\section{INTRODUCTION}

Reconstructing palaeo-ice sheet dynamics from offshore sedimentological and stratigraphic archives around the world has become an important topic of focus in the last decade (e.g., Dowdeswell and Ottesen, 2013; Stewart et al., 2013; Jakobsson et al., 2014; Sejrup et al., 2015; Hogan et al., 2016; Lamb et al., 2016; Dove et al., 2017; Greenwood et al., 2017; Streuff et al., 2017; Callard et al., 2018; Lockhart et al., 2018). Understanding how past ice sheets retreated in response to climate warming provides a vital analog for the projection of ice sheet behavior during future climate change (IPCC, 2013). As the projection of future sea-level rise depends on accurate modeling of ice-sheet retreat, sedimentology and stratigraphy plays a key role in addressing one of society's grand challenges (Hodgson et al., 2018).

Particular focus has been on understanding the dynamics of the British-Irish Ice Sheet during Marine Isotope Stage (MIS) $2(\sim 30-11.7 \mathrm{ka} \mathrm{BP})$ and, as such, it has become one of the best constrained palaeo-ice sheets (Clark et al., 2004, 2012, 2018). The extent and dynamics of northern and western sectors of the ice sheet has become well understood through both data and modeling approaches (Bradwell et al., 2007; Boston et al., 2010; Davies et al., 2011; Bradwell and Stoker, 2015; Peters et al., 2016; Smedley et al., 2017; Callard et al., 2018; Chiverrell et al., 2018; Gandy et al., 2018; Scourse et al., 2019). Confluence and interaction of the British-Irish and Scandinavian ice sheets in the North Sea Basin is unclear, and the maximum extent and dynamics of the ice sheet in the North Sea are still poorly constrained (Phillips et al., 2017b), with few studies into the controls of ice sheet advance and retreat (Cotterill et al., 2017a; Phillips et al., 2018; Roberts et al., 2018). Models imply a key, regional-scale influence of the British-Irish Ice Sheet in the North Sea Basin (Boulton and Hagdorn, 2006; Hubbard et al., 2009; Patton et al., 2016). At a local scale, the role of palaeo-ice streams and glacial hydrology in controlling ice-marginal dynamics has long been recognized (Stokes and Clark, 1999, 2001, 2003; Evans et al., 2008, 2014; Stewart et al., 2013; Margold et al., 2015; Stokes et al., 2015; Greenwood et al., 2016a,b; Stokes, 2018) but these processes have yet to be identified and described in the southern North Sea.

Proglacial lakes are a common feature of ice-sheet margins during deglaciation, with several lake-fills preserved in the Quaternary geological record (Carrivick and Tweed, 2013), and have been identified in many locations around the margin of the British-Irish Ice Sheet (Livingstone et al., 2010; Clark et al., 2012; Murton and Murton, 2012; Evans et al., 2016a, 2018). A large proglacial lake has been previously interpreted at Dogger Bank, with three phases of infill (Cotterill et al., 2017a). However, the detailed lake stratigraphy and environments of deposition, and the implications for landscape evolution and ice-sheet retreat, have not been documented previously.

In this study, we deduce the behavior of the ice sheet through investigation of an integrated, high resolution dataset from Dogger Bank, North Sea. Our aim is to describe the role of ice streaming and subglacial conditions on the advance, maximum extent and retreat of the ice sheet during MIS 2. Through investigation of the sedimentology and stratigraphy of glacial landforms and proglacial lake-fills, we identify for the first time a palaeo-ice stream and the controls on its subsequent retreat. We review the role of basal conditions on forming differing landsystems along the margin of the ice sheet at Dogger Bank. By combining local and regional geomorphic interpretation, we constrain the timing and maximum extent of the ice sheet in the southern North Sea.

\section{SETTING}

Dogger Bank is a large (approximately 15,000 $\mathrm{km}^{2}$ ), flattopped bank of sediment in the southern North Sea (Figure 1) that forms a present-day bathymetric high, between 18 and $63 \mathrm{~m}$ below mean sea level (MSL). Recent acquisition of highresolution seismic reflection data and geotechnical boreholes up to $50 \mathrm{~m}$ deep collected in support of windfarm site investigations have revealed the stratigraphic complexity of the Dogger Bank (Cotterill et al., 2017a,b; Phillips et al., 2018; Emery et al., 2019). A glacial origin was first suggested by Belt (1874), proposing it to be a bank of moraine sediment, later observed to be similar in scale to the Main Stationary Line of Denmark (Carr et al., 2006). Early investigations into the extent of the Last Glacial Maximum in the North Sea proposed small ice sheets terminating onshore or nearshore (Jansen et al., 1979; Sejrup et al., 1987; Long et al., 1988; Hall and Bent, 1990; Ehlers and Wingfield, 1991; Cameron et al., 1992; Phillips et al., 2017b). However, the presence of a large ice-sheet confluence in the North Sea was confirmed when the examination of cores and boreholes containing tills that were dated to the MIS 3-2 boundary (Sejrup et al., 2000) and contained evidence of significant subglacial deformation on Dogger Bank (Carr et al., 2006). Subsequent investigation of high-resolution seismic reflection data revealed a complex of large moraines (Cotterill et al., 2017a; Phillips et al., 2018), ground-truthed in vibrocores on the south-eastern flank of Dogger Bank (Emery et al., 2019), indicating ice sheet advance to at least the edge of Dogger Bank (Figure 1).

For the purposes of this study, the Late Pleistocene and Holocene stratigraphy of Dogger Bank can be simplified into four main formations (Table 1), which are applied to lithostratigraphic units in this study. The oldest of these formations is the Dogger Bank Formation that comprises massive clays, sands and diamicts of glacial origin (Cotterill et al., 2017a), subdivided informally in this study into the Lower and Upper Dogger Bank sub-units. On top of this, Botney Cut Formation proglacial lake sediments are observed (Cotterill et al., 2017a), informally subdivided in this study to the Upper, Lower and Basal Lake Dogger sub-units. The overlying three formations, one unnamed, the Elbow and the Nieuw-Zeeland Gronden formations (Table 1) are a mixture of clays, peats, silts, sands and gravels from terrestrial, fluvial, estuarine, coastal and shallow marine sedimentary environments (Cotterill et al., 2017a; Emery et al., 2019).

Onset of glaciation around the Dogger Bank area occurred via confluence of the British-Irish (or Celtic) and Scandinavian (or Fennoscandian) ice sheets around 30-29 ka BP, reaching its maximum extent by around $27 \mathrm{ka} \mathrm{BP}$ (Sejrup et al., 2000; Carr et al., 2006; Clark et al., 2012; Hughes et al., 2016; 

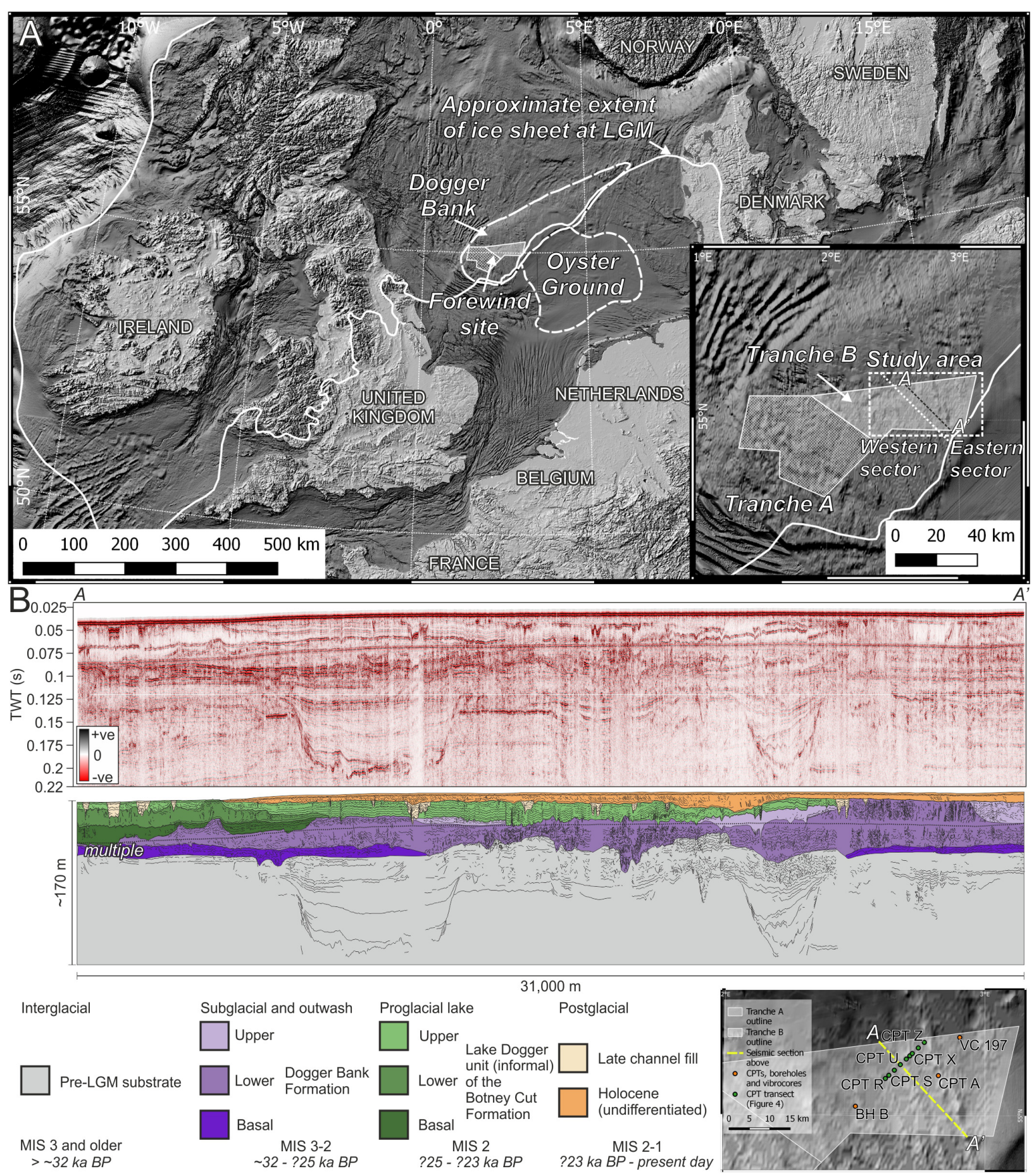

FIGURE 1 | (A) Location of Dogger Bank in the southern North Sea showing the location of the Forewind offshore wind project. Inset shows Tranches (A,B) of the Forewind project, and the area of focus for this study. Ice sheet extent combined from this study and Sejrup et al. (2005), Bradwell et al. (2008), and Ballantyne (2010). Bathymetry data: GEBCO (https://www.gebco.net). (B) Stratigraphic section through Dogger Bank showing the relationship between the pre-MIS 2 stratigraphy, Dogger Bank Formation glacial sediments, Botney Cut Formation proglacial lake sediments, and subsequent Late Pleistocene and Holocene sediments. Stratigraphy compiled from Cotterill et al. (2017a).

Roberts et al., 2018), although the exact timing and extent is poorly constrained. Ice retreated from Dogger Bank prior to 23 ka BP, shown by Optically Stimulated Luminescence (OSL) dating of proglacial ribbon lake deposits north of Dogger Bank (Roberts et al., 2018), rather than a late phase of rapid retreat caused by debuttressing at $18.5 \mathrm{ka}$ BP (Clark et al., 2012; 
TABLE 1 | Formations encountered within the study area, compiled from Stoker et al. (2011) and Cotterill et al. (2017a,b).

\begin{tabular}{|c|c|c|c|c|c|c|}
\hline $\begin{array}{l}\text { Group Stoker } \\
\text { et al., 2011; } \\
\text { Cotterill et al., } \\
2017 \text { a }\end{array}$ & Formation & Age & $\begin{array}{l}\text { Subdivisions } \\
\text { Cotterill et al., } \\
2017 \text { a }\end{array}$ & $\begin{array}{l}\text { Sedimentary } \\
\text { environment }\end{array}$ & $\begin{array}{l}\text { Description in Tranche B Cotterill } \\
\text { et al., 2017a }\end{array}$ & $\begin{array}{l}\text { Seismic velocity } \\
\text { Cotterill et al., } \\
2017 b\end{array}$ \\
\hline \multirow[t]{5}{*}{$\begin{array}{l}\text { California } \\
\text { Glaciogenic } \\
\text { Group }\end{array}$} & $\begin{array}{l}\text { Nieuw Zeeland } \\
\text { Gronden Formation }\end{array}$ & $\begin{array}{l}\text { Holocene, MIS } 1 \\
\text { Present day - } \\
6000 \mathrm{BP}\end{array}$ & $\begin{array}{l}\text { Terschellinger Bank } \\
\text { Member }\end{array}$ & Shallow marine & $\begin{array}{l}\text { Bioturbated marine sands, } \\
\text { transgressive gravel deposits Emery } \\
\text { et al., } 2019\end{array}$ & $1600 \mathrm{~m} / \mathrm{s}$ \\
\hline & Elbow Formation & $\begin{array}{l}\text { Holocene, MIS } 1 \\
\sim 11000 \mathrm{BP}- \\
\sim 6000 \mathrm{BP}\end{array}$ & & $\begin{array}{l}\text { Estuarine, } \\
\text { intertidal }\end{array}$ & $\begin{array}{l}\text { Tidal mudflats, barrier sands, peats and } \\
\text { silts Emery et al., } 2019\end{array}$ & $1600 \mathrm{~m} / \mathrm{s}$ \\
\hline & Unnamed & $\begin{array}{l}\text { Late Pleistocene, } \\
\text { MIS } 2 \\
\sim 17500 \mathrm{BP} \text { to } \\
\sim 11000 \mathrm{BP}\end{array}$ & & $\begin{array}{l}\text { Periglacial, } \\
\text { sandur and } \\
\text { glaciofluvial } \\
\text { outwash }\end{array}$ & $\begin{array}{l}\text { Not formally recorded within other } \\
\text { Formations. Well sorted sands, } \\
\text { evidence for cryoturbation. Extensive } \\
\text { channel networks exist in seismic } \\
\text { reflection data. }\end{array}$ & $1600 \mathrm{~m} / \mathrm{s}$ \\
\hline & $\begin{array}{l}\text { Botney Cut } \\
\text { Formation }\end{array}$ & $\begin{array}{l}\text { Late Pleistocene, } \\
\text { MIS } 2 \\
\text { ?deglacial stage, } \\
\sim 21000 \text { BP to } \\
\sim 17500 \text { BP }\end{array}$ & $\begin{array}{l}\text { Informally } \\
\text { subdivided in this } \\
\text { study to Upper, } \\
\text { Lower and Basal } \\
\text { Lake Dogger } \\
\text { sub-units. }\end{array}$ & Proglacial & $\begin{array}{l}\text { Found in an intra-moraine basin as } \\
\text { rhythmically laminated silts and very fine } \\
\text { sands with rare dropstones, interpreted } \\
\text { to be proglacial lake deposits. }\end{array}$ & $1650 \mathrm{~m} / \mathrm{s}$ \\
\hline & $\begin{array}{l}\text { Dogger Bank } \\
\text { Formation }\end{array}$ & $\begin{array}{l}\text { Late Pleistocene, } \\
\text { MIS } 2-4 \\
\sim 70000 \mathrm{BP}- \\
\sim 17500 \mathrm{BP}\end{array}$ & $\begin{array}{l}\text { Upper sub-unit } \\
\text { Lower sub-unit }\end{array}$ & $\begin{array}{l}\text { Glacial and } \\
\text { periglacial }\end{array}$ & $\begin{array}{l}\text { Upper Dogger Bank: Interbedded } \\
\text { sands and silty clays with some } \\
\text { clast-supported gravels. } \\
\text { Lower Dogger Bank: Massive clays } \\
\text { with some sand, silt and gravel, clays } \\
\text { with shell fragments, clays with chalk } \\
\text { clasts, and matrix-supported diamict } \\
\text { with chalk and flint, sand pods and } \\
\text { intraclasts. Micromorphology } \\
\text { suggesting subglacial deformation Carr } \\
\text { et al., } 2006 \text {, and often glaciotectonised } \\
\text { into arcuate ridges interpreted to be } \\
\text { moraines related to ice margin } \\
\text { oscillation Cotterill et al., 2017a; Phillips } \\
\text { et al., } 2018\end{array}$ & $1650 \mathrm{~m} / \mathrm{s}$ \\
\hline
\end{tabular}

Sejrup et al., 2016). On the western side of Dogger Bank (Tranche A of the Forewind windfarm site, Figure 1), ice-sheet retreat is characterized by multiple readvances forming thrust-block moraine complexes and glaciotectonic deformation of the Lower and Basal Dogger Bank sub-unit sediments (Table 1), implying an active, oscillating ice margin during deglaciation (Phillips et al., 2018). On the eastern side of Dogger Bank (Tranche B of the Forewind windfarm site, Figure 1), a large, proglacial lake has been identified (Cotterill et al., 2017a), hereafter named Lake Dogger, covering approximately $750 \mathrm{~km}^{2}$ with a sedimentary lake-fill sequence reaching up to $30 \mathrm{~m}$ thick. Stratigraphically, the lake basin occupies a depression between, and onlapping onto, moraine ridges (Figure 1). Cotterill et al. (2017a) suggested that these lake sediments form part of the Botney Cut Formation (BCF), although there is a marked difference in depositional environment between the proglacial lake-fill and the tunnel valley-fill of the rest of the BCF. The lake sediments overlie the Upper and Lower sub-units of the Dogger Bank Formation, and are incised by younger channels (Cotterill et al., 2017a), and truncated by wave ravinement surfaces (Emery et al., 2019).

The area covered in this study is shown in Figure 1. The study area covers the eastern side of Tranche B of the Forewind site. Due to differing observations of stratigraphic thicknesses of interpreted seismic units, the study area is subdivided into two sectors, east and west (Figure 1).

\section{MATERIALS AND METHODS}

A large, integrated sub-surface dataset of $2 \mathrm{D}$ seismic reflection profiles, geotechnical logs and sediment samples from boreholes and vibrocores were used in this study.

\section{Borehole, Geotechnical and Vibrocore Data}

\section{Vibrocore Data}

Twenty-five vibrocores were available throughout Tranche B, acquired by the British Geological Survey (BGS) between 1981 and 1994 as part of regional mapping programs. Vibrocores vary in length but can give continuous sediment recovery up to $6 \mathrm{~m}$ below seabed. Generally, the vibrocores are in good condition, although some desiccation has occurred in clay-rich sediments (Figure 2). 


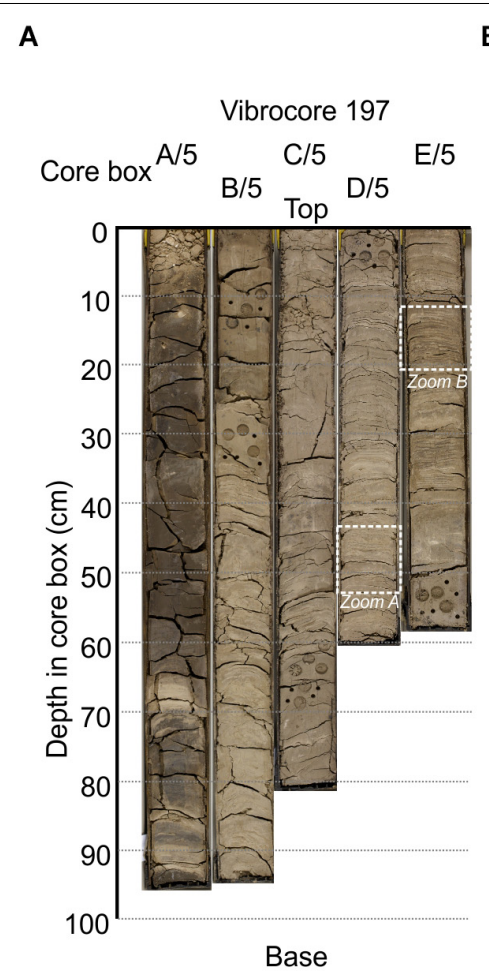

D

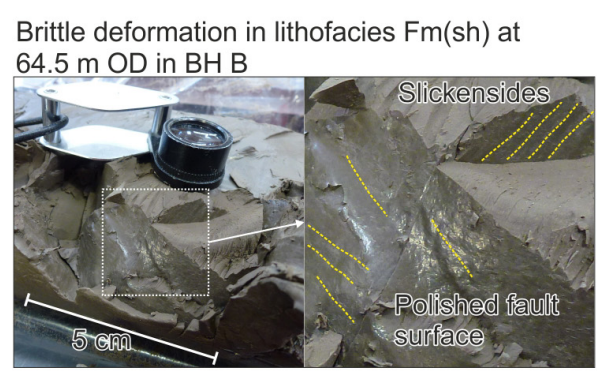

B
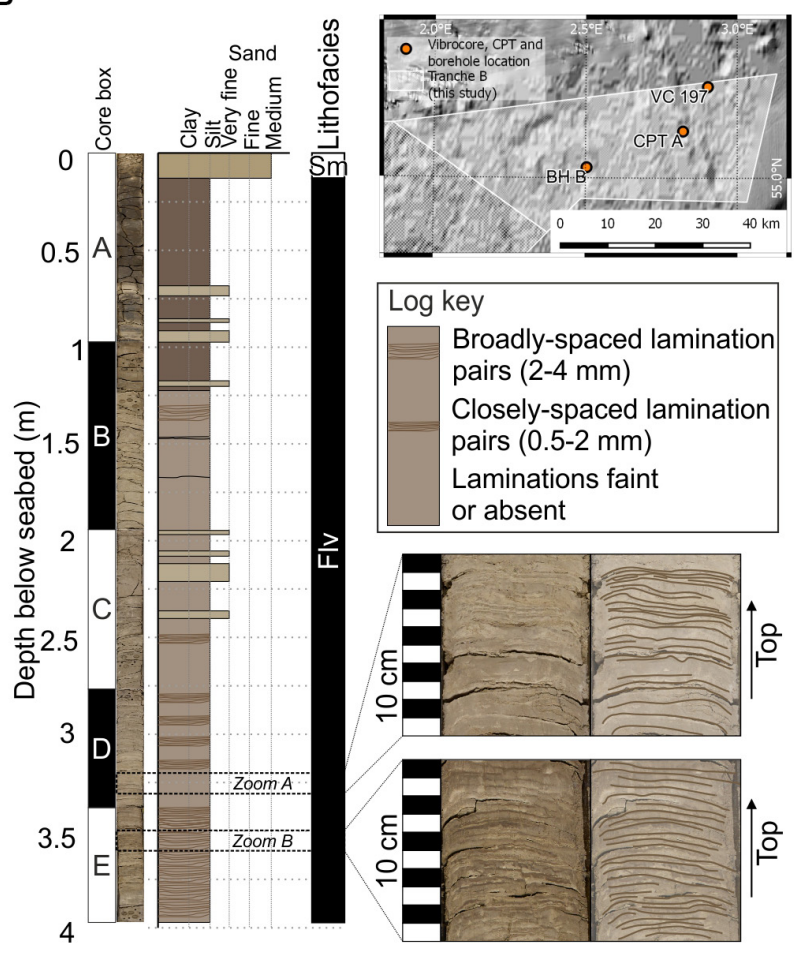

Log key

Broadly-spaced lamination pairs (2-4 mm)

Closely-spaced lamination pairs $(0.5-2 \mathrm{~mm})$

Laminations faint or absent

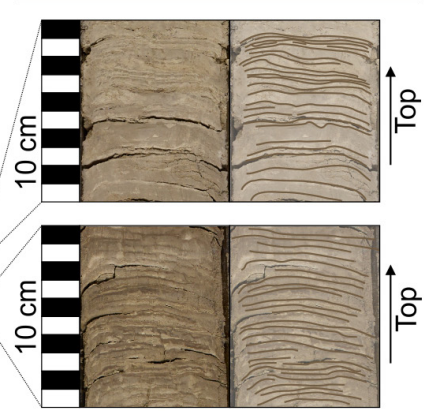

E

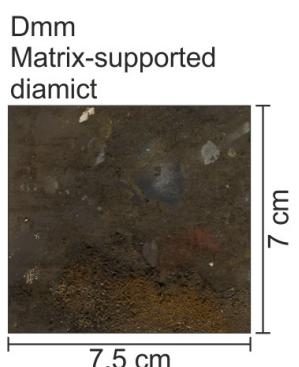

C

Cone resistance ( $\mathrm{MPa}$ ) Overconsolidation ratio CPT A

$0 \quad 102030405060$

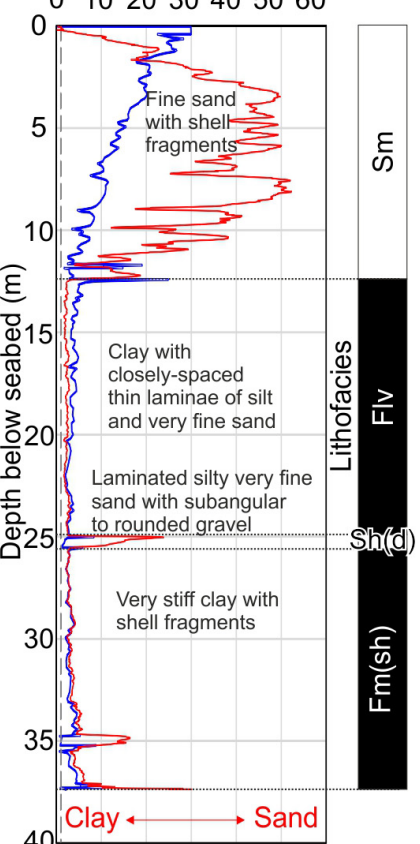

$\mathrm{Gm}$

Clast-supported gravel

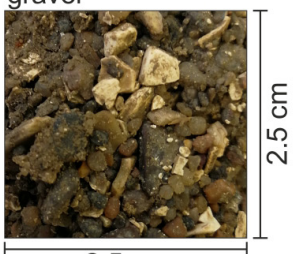

$2.5 \mathrm{~cm}$
Sm

Massive,

bioturbated sand

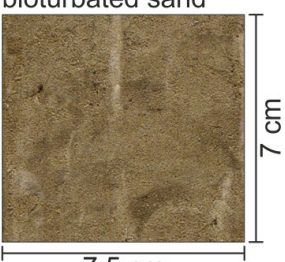

$7.5 \mathrm{~cm}$

FIGURE 2 | (A) Photograph of vibrocore 197 and (B) its sedimentary log with interpreted lithofacies, showing proglacial lake clay and silt rhythmites interpreted to be varves. Vibrocore 197 acquired June 1983, photograph date August 2017. (C) Log of Cone Penetration Test (CPT) A showing cone resistance plotted against depth. Low cone resistance represents clay (generally low friction) and high cone resistance represents sand (generally high friction). (D) Photograph of a short core section of borehole BH B showing brittle deformation in lithofacies Fm(sh). (E) Representative photographs of lithofacies Dmm (matrix-supported diamict), Gm (clast-supported gravel), and Sm (massive, bioturbated sand). For lithofacies descriptions see Table 4.

Sedimentary facies were identified from vibrocores and borehole samples based on visual grain size distribution, Munsell color, composition, texture and gradation, as well as use of sedimentary structures. Sedimentary facies were assigned lithofacies codes based on Evans and Benn (2004). Centimeterscale sediment logs were used to calibrate seismic facies and key seismic stratigraphic surfaces. Vibrocore depths were converted to seismic Two-Way Travel time (TWT) using the average velocities given in Table $\mathbf{1}$.

\section{Borehole and Geotechnical Logs}

Boreholes and Cone Penetration Tests (CPTs) up to $50 \mathrm{~m}$ deep were acquired as part of the Forewind site investigation dataset. Boreholes provide spot samples and short core sections (usually $<6 \mathrm{~cm}$, occasional $60 \mathrm{~cm}$ core lengths), spaced intermittently at intervals of 0.1-6 m, for geotechnical investigation. Twenty boreholes were drilled, each with a CPT, allowing for correlation of CPT response to each encountered sedimentary facies. A further $63 \mathrm{CPTs}$ were acquired throughout Tranche B. An example CPT log is shown in Figure 2. Borehole spot sample and $\mathrm{CPT}$ depths were converted to TWT using the average velocities given in Table 1.

\section{Seismic Reflection Data Interpretation Seismic Data}

A dense grid of 2D shallow seismic reflection data were acquired as part of the site investigation for the Forewind project. A total of 17,000 line $\mathrm{km}$ were available in Tranche B, along with an additional 6,000 line $\mathrm{km}$ of regional lines (Cotterill et al., 2017b). 
In Tranche B, 629 2D lines are spaced every $100 \mathrm{~m}$ in the NE-SW orientation, and 75 lines every 500-1000 $\mathrm{m}$ in the NW$\mathrm{SE}$ orientation. Regional lines are spaced at 2,500 $\mathrm{m}$ intervals in both the NW-SE and NE-SW orientations. Seismic data were handled using IHS Kingdom Suite. The profiles were acquired using a Sparker seismic source, with the Tranche B grid acquired at a higher resolution than the regional grid. The regional lines have a maximum vertical resolution of approximately $2-3 \mathrm{~m}$, and a maximum depth of investigation of approximately $180 \mathrm{~ms}$ below the seabed, equivalent to approximately $150 \mathrm{~m}$. The Tranche B grid has a similar depth of investigation, but a vertical resolution of $1 \mathrm{~m}$. Seismic reflection data are minimum phase. Data were interpreted using a black-red color scheme, with black for peaks and red for troughs (Figure 1). Horizons were interpreted on the peaks or troughs depending on the maximum amplitude observed, and interpreted consistently on the maximum amplitude.

Maps generated from interpreting seismic reflection data in two-way time were converted to depth using the P-wave velocities derived from local geotechnical data as well as the velocity of similar sediments recorded regionally in the North Sea, as given by Cotterill et al. (2017a). The sea water velocity was taken to be $1505 \mathrm{~m} / \mathrm{s}$ (Cotterill et al., 2017b). The velocity used to depth convert each formation is shown on Table 1. Individual interpreted seismic horizons were gridded in Kingdom Suite using the flex gridding algorithm, which provides geologically reasonable surfaces.

\section{Seismic Facies}

Seismic facies were used to distinguish stratigraphic units and correlate major surfaces and sedimentary environments. The terminology described by Mitchum et al. (1977) has been used. Closer investigation of seismic facies, which may traditionally have been described as reflection-free (or acoustically transparent) or chaotic using the Mitchum et al. (1977) terminology, has revealed seismic facies that provide a more detailed interpretation of glacial processes. Terminology to describe these seismic facies is presented and described in Table 2. These new seismic facies have been used in conjunction with the accepted terminology as described by Mitchum et al. (1977).

\section{RESULTS}

\section{Seismic Units}

Seismic facies and stratigraphic relationships were used to define seven main seismic units, described in Table 3. The stratigraphically oldest (SU-Basement) and youngest (SUPostglacial) units comprise multiple stratigraphic units, but remain undifferentiated in this study for the purposes of brevity. Stratigraphic relationships between each seismic unit are shown in Figure 3. Units are described from the stratigraphically oldest (SU-A) to youngest (SU-E).

\section{SU-Basement}

The lowest stratigraphic unit forms the basement to the study area (Figure 3). It comprises horizontal, low frequency, moderate to high amplitude reflectors. Large, up to $5 \mathrm{~km}$ wide, channel forms filled with low-frequency, medium amplitude, parallel reflectors are observed (Figure 1). The top of the seismic unit is defined by a continuous, high-amplitude reflector that separates SU-A from different seismic facies above.

\section{SU-A}

Seismic unit A is present throughout the study area, although its thickness is irregular. SU-A seismic facies are generally high amplitude, but inconsistent, and its geometry is also highly variable, forming mounds and ridges, as well as channel-fills that truncate the underlying SU-Basement. The ridges are 20 to $40 \mathrm{~m}$ high, 10 to $>27 \mathrm{~km}$ long, and generally orientated northeast-southwest. Mounds are 5 to $20 \mathrm{~m}$ high, $300 \mathrm{~m}$ wide, and 500 to $1000 \mathrm{~m}$ long. The channel-fills are generally 3-6 $\mathrm{m}$ deep, but can be up to $100 \mathrm{~m}$ deep. Seismic facies vary depending on geometry of the seismic unit. Seismic facies within the ridges of SU-A can be separated into distinct zones within the broader seismic unit (Figure 4). Two sets of inclined, asymmetric serrate reflectors have differing senses of vergence; one set verges to the northwest and the other verges to the southeast. These two sets surround a zone of symmetric serrate reflectors. These distinct structural domains occur within a long (at least $27 \mathrm{~km}$ within the study area), $5 \mathrm{~km}$ wide, $40 \mathrm{~m}$ high ridge. Internally, the mound forms are transparent to patchy. Where SU-A is thin, in areas between ridges and mounds, reflectors are high-amplitude, and can be continuous or inclined. Despite the variable geometries and seismic facies, SU-A is one seismic unit because of its stratigraphic position, bounded below by SU-Basement and above by a continuous, high-amplitude reflector marking an unconformity.

\section{SU-B}

Seismic unit B is present throughout the study area and downlaps onto the underlying seismic unit. In the eastern sector of the study area, its geometry is generally sheet-like and its thickness varies from absent to $10 \mathrm{~m}$. In the western sector of the study area, its thickness varies from 5 to $40 \mathrm{~m}$ (Figure 3). Seismic facies are generally low amplitude, with variable to transparent reflectors and high frequency, low amplitude, sigmoidal reflectors (Figure 3).

\section{SU-C}

Seismic unit $\mathrm{C}$ is present infilling a small basin in the north of the eastern sector of the study area. Its seismic facies are generally transparent. Reflectors onlap the underlying seismic units. The top of the unit is marked by a horizontal, high-amplitude reflector (Figure 5). SU-C is up to a maximum of $10 \mathrm{~m}$ thick.

\section{SU-D}

A lobate seismic unit D is present in the north of the study area. It thins toward the southeast and downlaps onto SU-C (where present) and SU-B (Figure 5). It is mainly transparent but also some patchy, inclined reflectors and asymmetrical serrate reflectors. It is a maximum of $10 \mathrm{~m}$ thick (Figure 5). 
TABLE 2 | Description of new seismic facies expanded from the terms "reflection-free" and "chaotic" Mitchum et al. (1977).

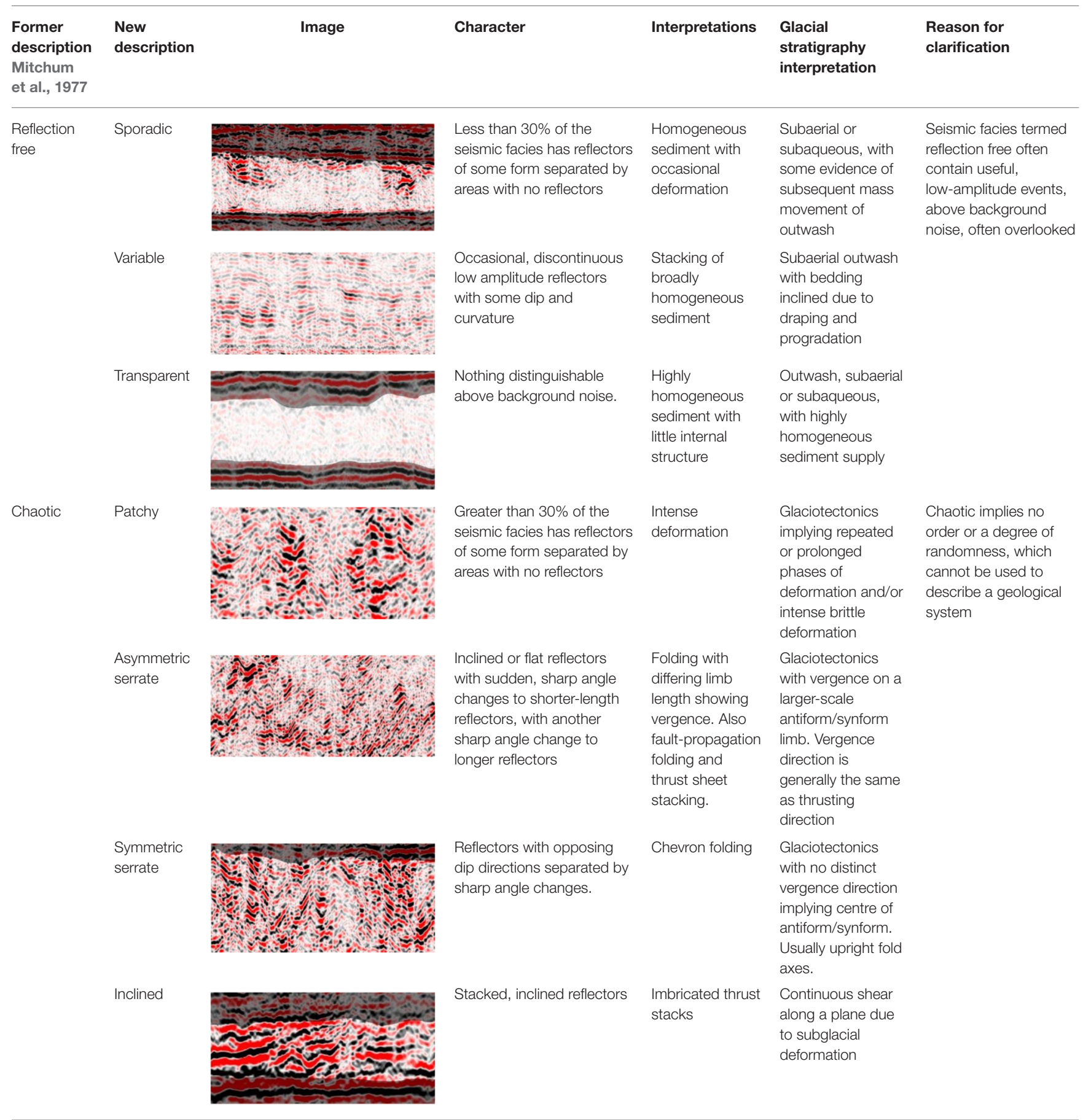

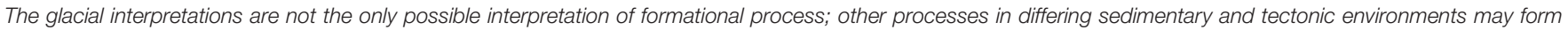
similar geometries. These new seismic facies are therefore able to be applied to different geological settings.

\section{SU-E}

Seismic unit E is characterized by high-frequency, mediumamplitude, continuous, parallel reflectors that are draped over the underlying stratigraphy, filling a large $\left(750 \mathrm{~km}^{2}\right)$ basin in the eastern sector of the study area formed by SU-A, SU-B and SU-D. SU-E drapes and onlaps the edges of its basin (Figure 5).
SU-E reaches a maximum thickness of $30 \mathrm{~m}$ in the center of its basin (Figure 1).

\section{SU-Postglacial}

The stratigraphically youngest seismic unit truncates or incises into previous units throughout the study area, except in the 
TABLE 3 | Descriptions of seismic facies, stratigraphic relationships and geometry used to define the seismic units (SUs) in this study.

\begin{tabular}{|c|c|c|c|c|}
\hline Seismic unit & $\begin{array}{l}\text { Seismic facies Table 2; Mitchum } \\
\text { et al., } 1977\end{array}$ & Geometry & $\begin{array}{l}\text { Stratigraphic } \\
\text { relationship }\end{array}$ & Other notes \\
\hline SU-Postglacial & $\begin{array}{l}\text { Low frequency, low amplitude } \\
\text { continuous parallel to sigmoidal } \\
\text { reflectors and medium to high } \\
\text { frequency, high amplitude, continuous } \\
\text { parallel reflectors }\end{array}$ & $\begin{array}{l}\text { Sheet (low amplitude), channel (high } \\
\text { amplitude) }\end{array}$ & $\begin{array}{l}\text { Truncation of, or } \\
\text { incision into, previous } \\
\text { seismic units }\end{array}$ & $\begin{array}{l}\text { Channel forms always appear } \\
\text { below the sheet forms. Channel } \\
\text { forms often cause acoustic } \\
\text { blanking below. }\end{array}$ \\
\hline SU-E & $\begin{array}{l}\text { High frequency, medium amplitude, } \\
\text { continuous, parallel, draped reflectors }\end{array}$ & Sheet & $\begin{array}{l}\text { Onlaps onto SU-D and } \\
\text { SU-A. Draped over } \\
\text { SU-D, D and E. }\end{array}$ & $\begin{array}{l}\text { Occasionally discontinuous and } \\
\text { inclined. }\end{array}$ \\
\hline SU-D & $\begin{array}{l}\text { Mainly transparent with some patchy, } \\
\text { inclined reflectors and asymmetric } \\
\text { serrate reflectors. }\end{array}$ & Lobate, thinning toward southeast & $\begin{array}{l}\text { Downlaps onto SU-C } \\
\text { (where present) and } \\
\text { SU-B }\end{array}$ & $\begin{array}{l}\text { No distinct, continuous top } \\
\text { reflector. }\end{array}$ \\
\hline SU-C & Transparent & Basin fill & Onlaps SU-B and E. & High amplitude top reflector \\
\hline SU-B & $\begin{array}{l}\text { High frequency, low amplitude } \\
\text { sigmoidal reflectors and variable } \\
\text { reflectors }\end{array}$ & $\begin{array}{l}\text { Varying. Lobate, sheet, channel, mound, } \\
\text { basin fill. }\end{array}$ & $\begin{array}{l}\text { Downlaps and onlaps } \\
\text { onto SU-A depending } \\
\text { on morphology }\end{array}$ & $\begin{array}{l}\text { Complex occurrence and } \\
\text { relationship with SU-A. Can be } \\
\text { difficult to differentiate from SU-A. }\end{array}$ \\
\hline SU-A & $\begin{array}{l}\text { Many differing facies. Asymmetric } \\
\text { serrate, symmetric serrate, and inclined } \\
\text { reflectors, and patchy and sporadic } \\
\text { reflectors. High amplitude, continuous } \\
\text { inclined reflectors also present. }\end{array}$ & $\begin{array}{l}\text { Mounds, ridges, sheet, channels of } \\
\text { varying scale. Ridges up to } 40 \mathrm{~m} \text { high } \\
\text { and } 30 \mathrm{~km} \text { long. Mounds up to } 20 \mathrm{~m} \text { high } \\
\text { and } 1 \mathrm{~km} \text { long. Channels up to } 100 \mathrm{~m} \\
\text { deep, } 200 \mathrm{~m} \text { wide and } 50 \mathrm{~km} \text { long. }\end{array}$ & $\begin{array}{l}\text { Concordant with, or } \\
\text { incises into, basement }\end{array}$ & $\begin{array}{l}\text { Complex morphology and } \\
\text { arrangement of multiple seismic } \\
\text { facies }\end{array}$ \\
\hline SU-Basement & $\begin{array}{l}\text { Low frequency, high amplitude parallel } \\
\text { reflectors }\end{array}$ & $\begin{array}{l}\text { Sheet and large channels ( } 5 \mathrm{~km} \text { wide in } \\
\text { places) }\end{array}$ & Basal & $\begin{array}{l}\text { Often below the maximum depth of } \\
\text { investigation. }\end{array}$ \\
\hline
\end{tabular}

Seismic facies terminology is from Mitchum et al. (1977) and Table 2.

southeastern corner of the study area, where it is concordant with underlying stratigraphy (Figure 1). It comprises low-amplitude, low-frequency, discontinuous parallel to sigmoidal reflectors in a sheet geometry, and high-amplitude continuous reflectors within channel forms. The channel forms are stratigraphically lower than the sheet forms (Figure 3).

\section{Sedimentary Facies}

Nine main lithofacies were identified from vibrocores, CPT logs and borehole samples. Full descriptions of these lithofacies are given in Table 4. Images of the lithofacies, where available, are shown in Figure 2. Colors given in the descriptions below refer to Munsell color names; full color details are given in Table 4.

\section{Dmm - Matrix-Supported Diamict}

A brown diamict was recovered from vibrocores in the southeast of the study area. Grain size varies from silty clay to very large pebbles (Figure 2). The clasts are predominantly subangular and striated. Rip-up clasts and sand inclusions are also found within lithofacies Dmm.

\section{Flv - Finely Laminated Silts and Clays}

A grayish-brown silt and a dark brown clay in alternating laminae were recovered from vibrocores and boreholes, and calibrate to a distinct low cone resistance in CPT logs as seen in CPT A (Figure 2). Pairs of laminae vary in thickness from 0.5 to $4 \mathrm{~cm}$. Lithofacies Flv is shown in vibrocore 197 in Figure 2.

\section{Fm - Clay}

Lithofacies Fm was not recovered in vibrocores or boreholes, but is penetrated by CPTs such as CPT V (Figure 3). The very low cone resistance implies it is a massive clay.

\section{Fm(sh) - Massive Silty Clay With Shell Fragments}

A very dark grayish brown silty clay was recovered in borehole samples. The short core segments $(0.6 \mathrm{~m})$ show the clay to be massive and contain shell fragments, chalk clasts and fine gravel. Slickensides are present along polished planes that are present within the core segment (Figure 2). The clay is very stiff and overconsolidated.

\section{Gm - Clast-Supported Gravel}

A very dark grayish brown clast-supported gravel was recovered from a borehole spot sample. The matrix comprises silty clay. Clasts are small to medium pebbles in size. The gravel is stiff and overconsolidated. Clasts are of mixed lithology and occasional shell fragments are present. No sedimentary structures are evident. Lithofacies $\mathrm{Gm}$ is shown in Figure 2.

\section{Sh(d) - Laminated Silty Fine Sand With Dropstones}

A dark grayish-brown sand was logged in CPT A (Figure 2). Borehole samples show the sand to be laminated and containing occasional subangular to rounded gravel and pockets of clay.

\section{SI(o)/FI(o) - Interbedded Sands and Clays With Organic Matter}

The interbedded lithofacies $\mathrm{Sl}(\mathrm{o}) / \mathrm{Fl}(\mathrm{o})$ was not recovered in continuous cores. Isolated spot samples show the sand to be grayish-brown fine sand interbedded with very dark grayish-brown clays. Both sand and clay interbeds contain abundant peat fragments and organic material. Lithofacies $\mathrm{Sl}(\mathrm{o}) / \mathrm{Fl}(\mathrm{o})$ has a highly variable CPT log response in $\mathrm{CPTs} \mathrm{V}$ and $\mathrm{W}$ (Figure 3) responding to the interbedding of sand and clay. 


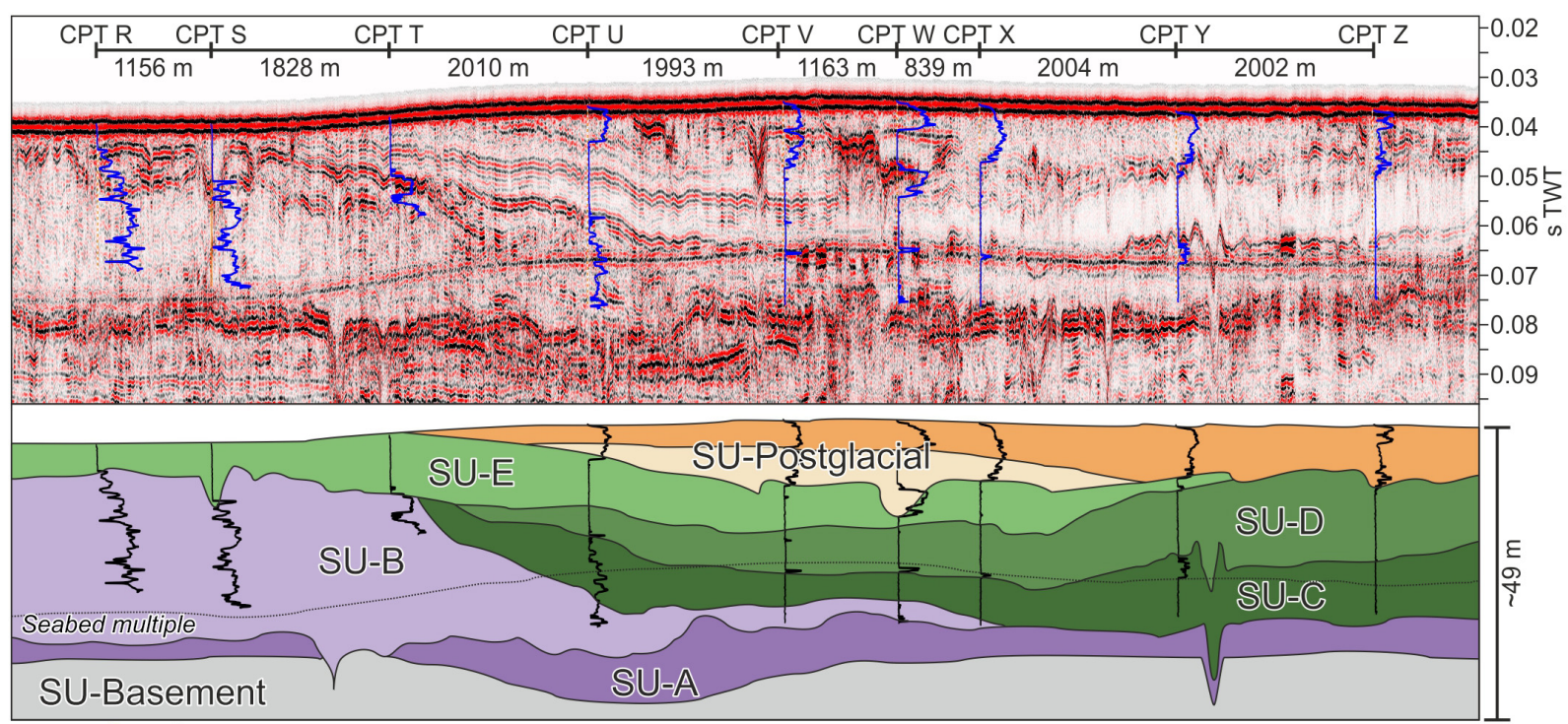

Pre-LGM substrate
logs
Clay $<>$ Sand recovered in
study area)

Lower Dogger Bank

Formation: Clay-dominated

with diamicts and shell

fragments.

Lithofacies Fm(sh), Dmm

Upper Dogger Bank

Formation: Mainly sand and silt with some gravel. Lithofacies SI/FI, Gm

Upper Lake Dogger

unit: Laminated

silt and clay varves.

Lithofacies Flv

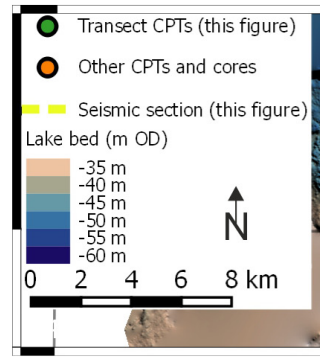

Basal Lake Dogger

unit: Clay with some silt in delta foresets, clay distally. Lithofacies Fm

Postglacial channel

fill: Interbedded

sands and clays with

organic matter. Lithofacies SI(0)/FI(0)

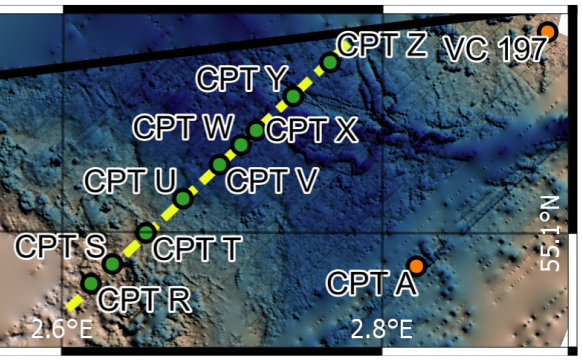

Lower Lake Dogger unit: Massive clay with fine sand with dropstones at the base.

\section{Lithofacies Fm, Sh(d)}

Holocene: Sands with

abundant shell fragments.

Sand and silty clay interbeds. Lithofacies Sm

FIGURE 3 | Transect through CPTs showing correlation between lithofacies observed in core and borehole samples, their CPT log characteristics, and seismic facies. Seismic units are described in Table 3. For descriptions of lithofacies see Table 4.

SI/FI - Interbedded Sand and Sandy Clay

A further lithofacies of interbedded sand and clay was recovered in isolated borehole spot samples. This lithofacies varies from $\mathrm{Sl}(\mathrm{o}) / \mathrm{Fl}(\mathrm{o})$ by its lack of organic material. The medium to fine sand is dark grayish brown and the sandy clay is very dark grayish brown. The highly variable CPT $\log$ response in CPTs R and S implies it is interbedded (Figure 3). The sand is moderately to poorly sorted and occasionally contains fine to coarse gravel and small shell fragments. Some clasts are striated.

\section{Sm - Massive, Bioturbated Sand}

A massive, very fine to fine, dark grayish brown sand was recovered at and immediately below the seabed in vibrocores and boreholes. The sand is well sorted and contains abundant whole shells and large $(1-2.5 \mathrm{~cm})$ shell fragments. Its mottled appearance suggests it could be bioturbated. Lithofacies $\mathrm{Sm}$ is shown in Figure 2.

\section{INTERPRETATION OF RESULTS}

\section{Stratigraphic Architecture and Geomorphology}

In map view, key surfaces between each seismic unit reveal buried geomorphology that provide further evidence of ice-sheet retreat behavior in the study area (cf. Cotterill et al., 2017a,b; 


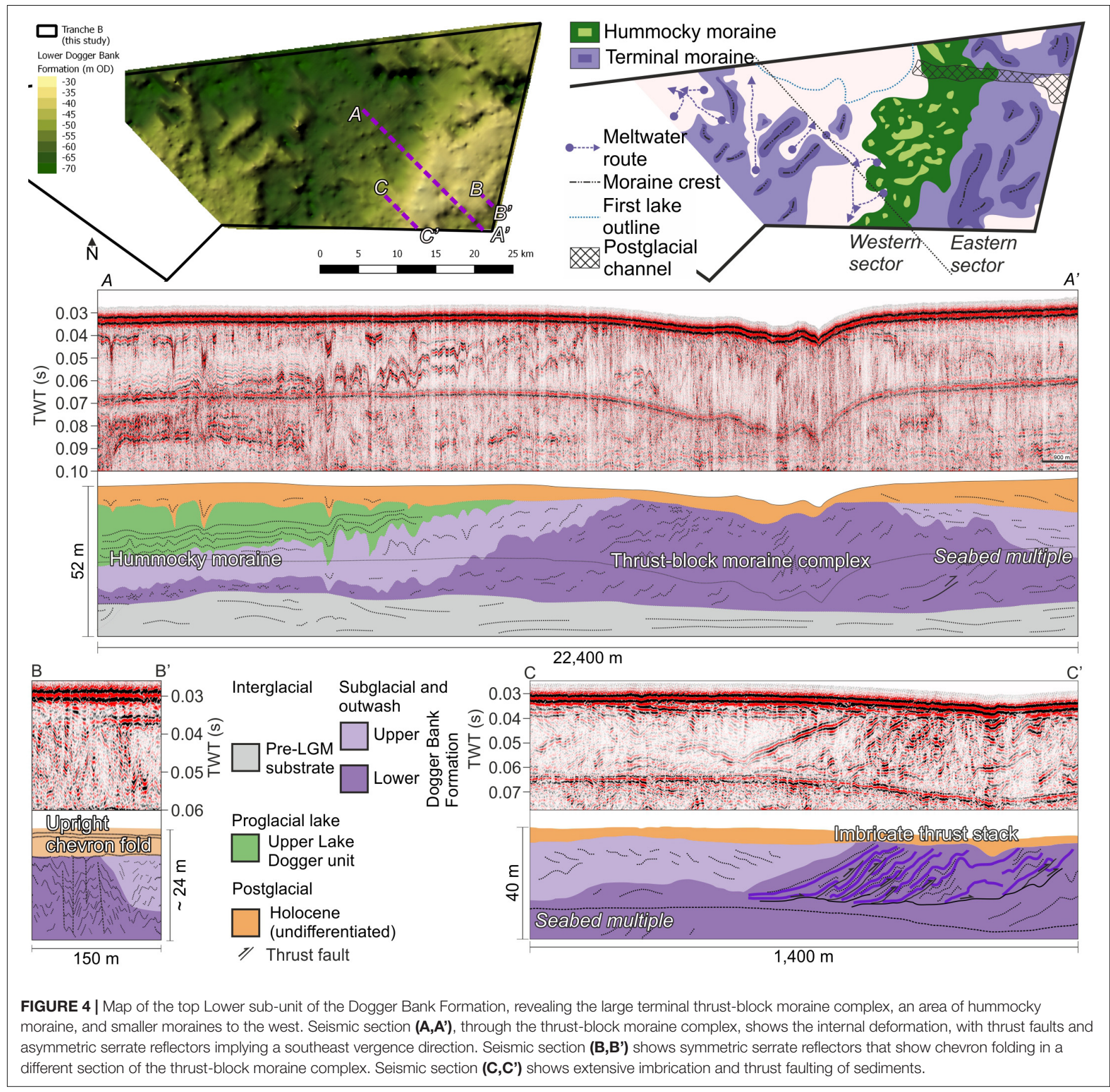

Phillips et al., 2018). These geomorphological features are described in stratigraphic order, from oldest to youngest.

\section{Subglacial Bedforms}

A series of elongate mounds are present at the top of seismic unit $\mathrm{A}$. The mounds are rounded, and generally up to $16 \mathrm{~m}$ high, $300 \mathrm{~m}$ wide, and $1000 \mathrm{~m}$ long (Figure 6). Seismic facies within the mounds are characterized by patchy, inclined, asymmetric serrate reflectors that imply a degree of deformation. The elongate mounds mainly occur in the eastern sector of the study area, although a single mound that is over $10 \mathrm{~km}$ long exists in the western sector. On the basis of their morphology, stratigraphic position and seismic facies, the mounds are interpreted as subglacially streamlined bedforms. Their dimensions conform to many subglacially streamlined bedforms observed globally (Spagnolo et al., 2014; Ely et al., 2016; Jamieson et al., 2016), and are similar in dimension to many drumlins and mega-scale glacial lineations observed elsewhere in the former British-Irish and Scandinavian ice sheets, and in areas with low topographic relief (e.g., Hughes et al., 2010; Evans et al., 2014; Greenwood et al., 2016b; Chiverrell et al., 2018; Delaney et al., 2018; Hermanowski et al., 2019). Two distinct sets of elongation direction are observed within these postulated subglacial bedforms. In the eastern sector of the study area, the bedforms are generally 


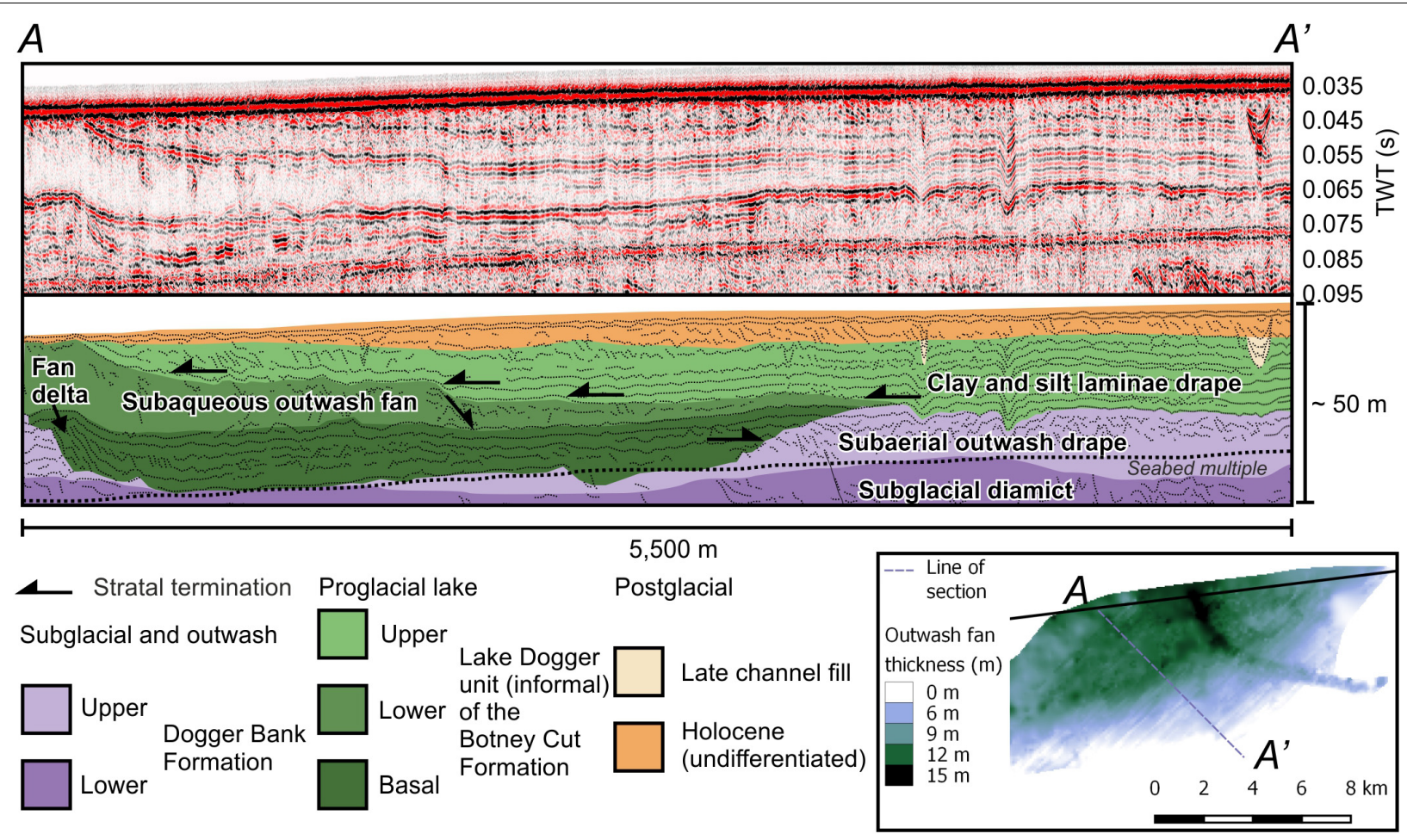

FIGURE 5 | Stratigraphic section showing the proglacial lake stratigraphic relationships. Inset: Isopach map of the Lower Lake Dogger sub-unit showing its lobate geometry, thinning toward the east and south.

elongate about a northeast-southwest axis. In the western sector of the study area, the mound is elongate about a north-south axis (Figure 6).

At the same stratigraphic level as the streamlined bedforms, in the eastern sector of the study area, are four northwest-southeasttrending sinuous ridges, up to $15 \mathrm{~m}$ high, but generally 5-10 m high, $100 \mathrm{~m}$ wide and greater than $4000 \mathrm{~m}$ long, extending beyond the study area (Figure 6). Internally, medium amplitude, low frequency, subhorizontal, parallel reflectors imply bedding. At the southeastern tip of the ridge, a broad, flat-topped mound is observed, with evidence of stratification. Because of their sinuous ridge morphology with internal bedding, these ridges are interpreted as eskers (Banerjee and McDonald, 1975; Aylsworth and Shilts, 1989; Storrar et al., 2014a,b), which drained sedimentladen meltwater into an outwash fan or small subglacial lake at its southeastern tip. The eskers form a connected network of ridges, interpreted to be a braided esker network in the basis of the channel relationships (Auton, 1992).

Numerous channel forms incise into the subglacial Lower subunit of the Dogger Bank Formation and the underlying pre-LGM substrate (Figure 6). The channels are 25 to $75 \mathrm{~m}$ wide, 3 to $8 \mathrm{~m}$ deep, and vary in length from 0.9 to $5 \mathrm{~km}$. One large channel exists on the border between the eastern and western sectors of the study area, and is an order of magnitude larger than the other channels, being $500 \mathrm{~m}$ wide, up to $25 \mathrm{~m}$ deep and over $10 \mathrm{~km}$ long, extending out of the study area. This channel has an undulating thalweg and is slightly sinuous, running northwest to southeast. Networks of the smaller channels vary between the eastern and western sectors. In the east, channels are dendritic and are orientated northwest-southeast. Their orientations are approximately the same as the orientations of the subglacially streamlined bedforms and eskers. There is a change from eskerto channel-dominated landforms associated with a thickening of the till to the southeast (Figure 6). In the western side of the study area, there are fewer channels, and the networks are non-dendritic, anastomosing, orientated north-south, and show abrupt terminations at both ends of the channel (Figure 6). Both channel networks erode into the substrate. Despite the differences in networks between the eastern and western sectors, the channels have been interpreted as subglacial meltwater channels on the basis of their network, termination style, erosion into the substrate, and morphology (Greenwood et al., 2007; Pearce et al., 2017).

\section{Moraines}

The large composite ridge formed by SU-A in the eastern sector of the study area (Figure 4) comprises multiple smaller ridge crests within one main ridge, orientated from north-northeast to south-southwest that is up to $40 \mathrm{~m}$ high, $10 \mathrm{~km}$ wide and extends at least $27 \mathrm{~km}$. The ridge is slightly arcuate. The southeastverging internal deformation within the ridges, combined with their morphology, imply that these ridges form a thrust-block moraine complex (Benn and Evans, 2010 and references therein) as ice moved from northwest to southeast.

To the northwest of the thrust-block moraine complex, and to the southeast of the subglacial landforms described above, is an 
TABLE 4 | Lithofacies descriptions as observed in vibrocores and borehole samples.

\begin{tabular}{|c|c|c|c|c|c|}
\hline $\begin{array}{l}\text { Lithofacies code } \\
\text { (based on Evans } \\
\text { and Benn, 2004) }\end{array}$ & $\begin{array}{l}\text { Short } \\
\text { description }\end{array}$ & Munsell color & Grain size & Sedimentary structures & Other notes \\
\hline $\mathrm{Gm}$ & $\begin{array}{l}\text { Clast- } \\
\text { supported } \\
\text { gravel }\end{array}$ & $\begin{array}{l}\text { Very dark grayish } \\
\text { brown 10YR } 3 / 2 \text { (clay } \\
\text { matrix) }\end{array}$ & $\begin{array}{l}\text { Silty clay to medium } \\
\text { pebbles }(\Phi-3)\end{array}$ & Massive & $\begin{array}{l}\text { Very stiff, consolidated, clast-supported } \\
\text { gravel with shell fragments and clasts of } \\
\text { mixed lithology. }\end{array}$ \\
\hline Dmm & $\begin{array}{l}\text { Matrix- } \\
\text { supported } \\
\text { diamict }\end{array}$ & Brown 10YR 4/3 & $\begin{array}{l}\text { Silty clay to very large } \\
\text { pebbles }(\Phi-6)\end{array}$ & Massive & $\begin{array}{l}\text { Clasts angular to subrounded, } \\
\text { predominantly subangular, consisting of } \\
\text { mixed lithologies. Some striations } \\
\text { preserved on clasts. Rip-up clasts and } \\
\text { inclusions of sand. }\end{array}$ \\
\hline Flv & $\begin{array}{l}\text { Finely } \\
\text { laminated silts } \\
\text { and clays }\end{array}$ & $\begin{array}{l}\text { Grayish brown 10YR } \\
5 / 2 \text {, light brownish gray } \\
2.5 Y \text { Y } 6 \text { (silt), dark } \\
\text { brown } 7.5 Y R 3 / 2 \text { (clay), } \\
\text { light yellowish brown } \\
2.5 Y \text { 6/3 (very fine } \\
\text { sand) }\end{array}$ & $\begin{array}{l}\text { Silt ( } \Phi 6 \text { to } 8 \text { ) and clay } \\
(\Phi 10) \text { with some very } \\
\text { fine sand (up to } \Phi 4)\end{array}$ & $\begin{array}{l}\text { Alternating laminae of clay } \\
\text { and silt. Laminae pairs } 0.5 \text { to } \\
4 \mathrm{~cm} \text { thick. Some occasional } \\
\text { ball-and-pillow structures and } \\
\text { convolute bedding. Patches } \\
\text { of very fine sand may occur, } \\
\text { with clay-silt laminae draped } \\
\text { over. }\end{array}$ & $\begin{array}{l}\text { Very fine sand appears in thin } \\
\text { laminations, } 1-2 \mathrm{~cm} \text {, fining upward, of } \\
\text { differing frequency, but remains rare } \\
\text { (every } 25-50 \mathrm{~cm} \text { ) }\end{array}$ \\
\hline $\mathrm{Fm}(\mathrm{sh})$ & $\begin{array}{l}\text { Massive silty } \\
\text { clay }\end{array}$ & $\begin{array}{l}\text { Very dark grayish } \\
\text { brown 10YR } 3 / 2\end{array}$ & $\begin{array}{l}\text { Clay }(\Phi 10) \text { with some } \\
\text { silt }(\Phi 8)\end{array}$ & Massive & $\begin{array}{l}\text { Occasional shell fragments, chalk clasts } \\
\text { and fine gravel. Some planes with } \\
\text { slickensides preserved. }\end{array}$ \\
\hline $\mathrm{Fm}$ & Clay & Not recovered & $\begin{array}{l}\text { Clay }(\Phi 10) \text { with some } \\
\text { silt }(\Phi 8)\end{array}$ & $\begin{array}{l}\text { Not observed in continuous } \\
\text { cores }\end{array}$ & Overconsolidated. Not recovered. \\
\hline $\operatorname{Sh}(d)$ & $\begin{array}{l}\text { Laminated silty } \\
\text { fine sand with } \\
\text { dropstones }\end{array}$ & $\begin{array}{l}\text { Dark grayish brown } \\
2.5 Y 4 / 2 \text { (sand) }\end{array}$ & $\begin{array}{l}\text { Very silty ( } \Phi \text { } 6 \text { to } 8 \text { ) fine } \\
\text { sand ( } \Phi 3 \text { to } 4) \text { with fine } \\
\text { gravel }(\Phi-2 \text { to }-3)\end{array}$ & Sand laminated (0.5 to $2 \mathrm{~cm})$. & $\begin{array}{l}\text { Gravel is subangular to rounded and of } \\
\text { mixed lithology. Pockets of clay } \\
\text { present. Poorly sorted. }\end{array}$ \\
\hline $\mathrm{SI}(\mathrm{O}) / \mathrm{Fl}(\mathrm{O})$ & $\begin{array}{l}\text { Interbedded } \\
\text { sands and } \\
\text { clays with } \\
\text { organic matter }\end{array}$ & $\begin{array}{l}\text { Grayish brown } 2.5 Y 5 / 2 \\
\text { (sand), very dark } \\
\text { grayish brown 10YR } \\
3 / 2 \text { (clay) }\end{array}$ & $\begin{array}{l}\text { Fine sand ( } \Phi 2 \text { to } 3) \\
\text { with sandy clay }(\Phi 10)\end{array}$ & $\begin{array}{l}\text { Not observed in continuous } \\
\text { cores }\end{array}$ & $\begin{array}{l}\text { Mica-rich. Abundant organic material, } \\
\text { peat fragments. }\end{array}$ \\
\hline $\mathrm{SI} / \mathrm{FI}$ & $\begin{array}{l}\text { Interbedded } \\
\text { sand and } \\
\text { sandy clay }\end{array}$ & $\begin{array}{l}\text { Dark grayish brown } \\
2.5 Y 4 / 2 \text { (sand), very } \\
\text { dark grayish brown } \\
\text { 10YR } 3 / 2 \text { (clay) }\end{array}$ & $\begin{array}{l}\text { Medium to fine sand ( } \Phi \\
1 \text { to } 3) \text { and clay }(\Phi 10) \\
\text { with very fine sand }(\Phi \\
\text { 4) and silt ( } \Phi 6 \text { to } 8) \text {. }\end{array}$ & $\begin{array}{l}\text { Not observed in continuous } \\
\text { cores }\end{array}$ & $\begin{array}{l}\text { Moderately to poorly sorted sand, } \\
\text { occasionally with fine to coarse gravel, } \\
\text { frequent granule-sized chalk. Some } \\
\text { striations preserved on clasts. Small } \\
\text { shell fragments frequent. Interbed } \\
\text { thickness varies greatly. }\end{array}$ \\
\hline Sm & $\begin{array}{l}\text { Massive very } \\
\text { fine to fine sand }\end{array}$ & $\begin{array}{l}\text { Dark grayish brown } \\
2.5 Y 4 / 2 \text {, olive brown } \\
2.5 Y 4 / 3\end{array}$ & $\begin{array}{l}\text { Very fine to fine sand }(\Phi \\
2 \text { to } 4)\end{array}$ & Some bioturbation. & $\begin{array}{l}\text { Well sorted. Contains whole shells and } \\
\text { abundant shell fragments. Mottled } \\
\text { texture. }\end{array}$ \\
\hline
\end{tabular}

area of irregular, hummocky topography that internally show evidence for deformation within the seismic facies (Figure 4). The thin unit of deformed seismic facies with a hummocky top surface implies subglacial deformation of fine-grained tills. This is consistent with hummocky moraines, similar to those observed close to the margin of the former Laurentide ice sheet (Evans and Rea, 1999; Eyles et al., 1999; Boone and Eyles, 2001; Evans et al., 2014).

Smaller moraine ridges also exist in the western sector of the study area (Figure 4). The moraines are up to $10 \mathrm{~km}$ long, $2 \mathrm{~km}$ wide, and $15 \mathrm{~m}$ high, and are narrower and single-crested, implying a different formational process to the large thrustblock moraine complex. Furthermore, these moraine ridges trend northeast to southwest, and are generally more arcuate than the thrust-block moraine complex. The relative scale and geometry of these buried glacial landforms are comparable to those described by Phillips et al. (2018), $50 \mathrm{~km}$ to the southwest, as having formed during the active retreat of the ice sheet northward across Dogger Bank.

\section{Lake Basin Morphology}

The stratigraphically lowest lake-fill sediments of the Basal Lake Dogger sub-unit occur in the north of the eastern sector of the study area (Figure 4), whilst the Lower and Upper Lake Dogger sub-units are laterally more extensive and can be traced across most of the eastern sector of the study area (Figure 7). The initial lake basin, represented by the Basal Lake Dogger sub-unit sediments, has been mapped over an area of at least $90 \mathrm{~km}^{2}$ within the study area (Figure 4), but extends further north outside of the data coverage. Typically, this basal sedimentary unit is 10 to $12 \mathrm{~m}$ thick, but reaches a maximum thickness of $20 \mathrm{~m}$. The subsequent, more areally extensive lake is represented by the Lower and Upper Lake Dogger sub-units and forms an elongate north-south trending basin, which is over $43 \mathrm{~km}$ in length (extending beyond data coverage) and up to $17 \mathrm{~km}$ wide, and covers an area of over $700 \mathrm{~km}^{2}$ (Figure 7). The sediments (combined Lower and Upper Lake Dogger sub-units) within this lake basin reach a maximum thickness of $30 \mathrm{~m}$ (Figure 1). 


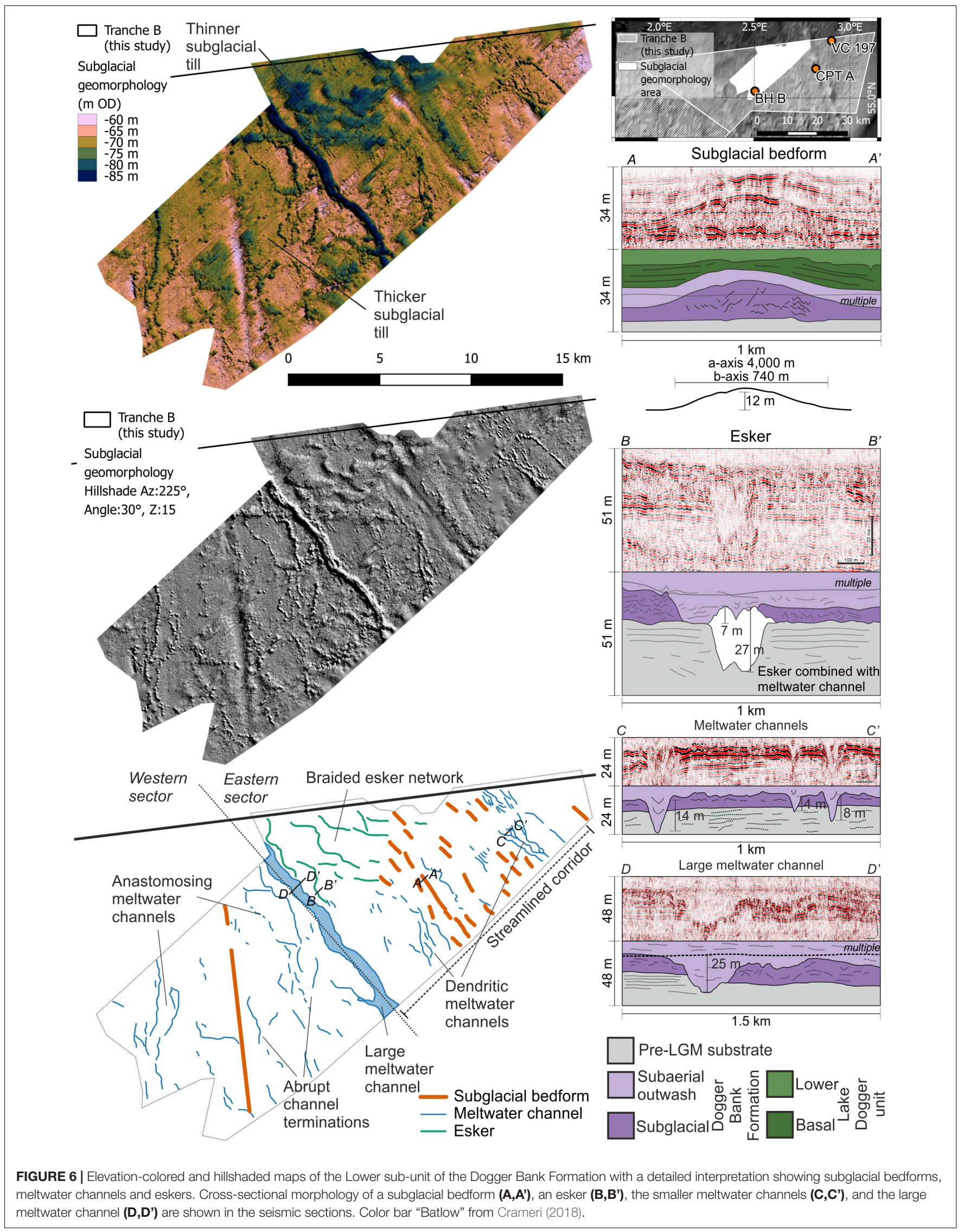



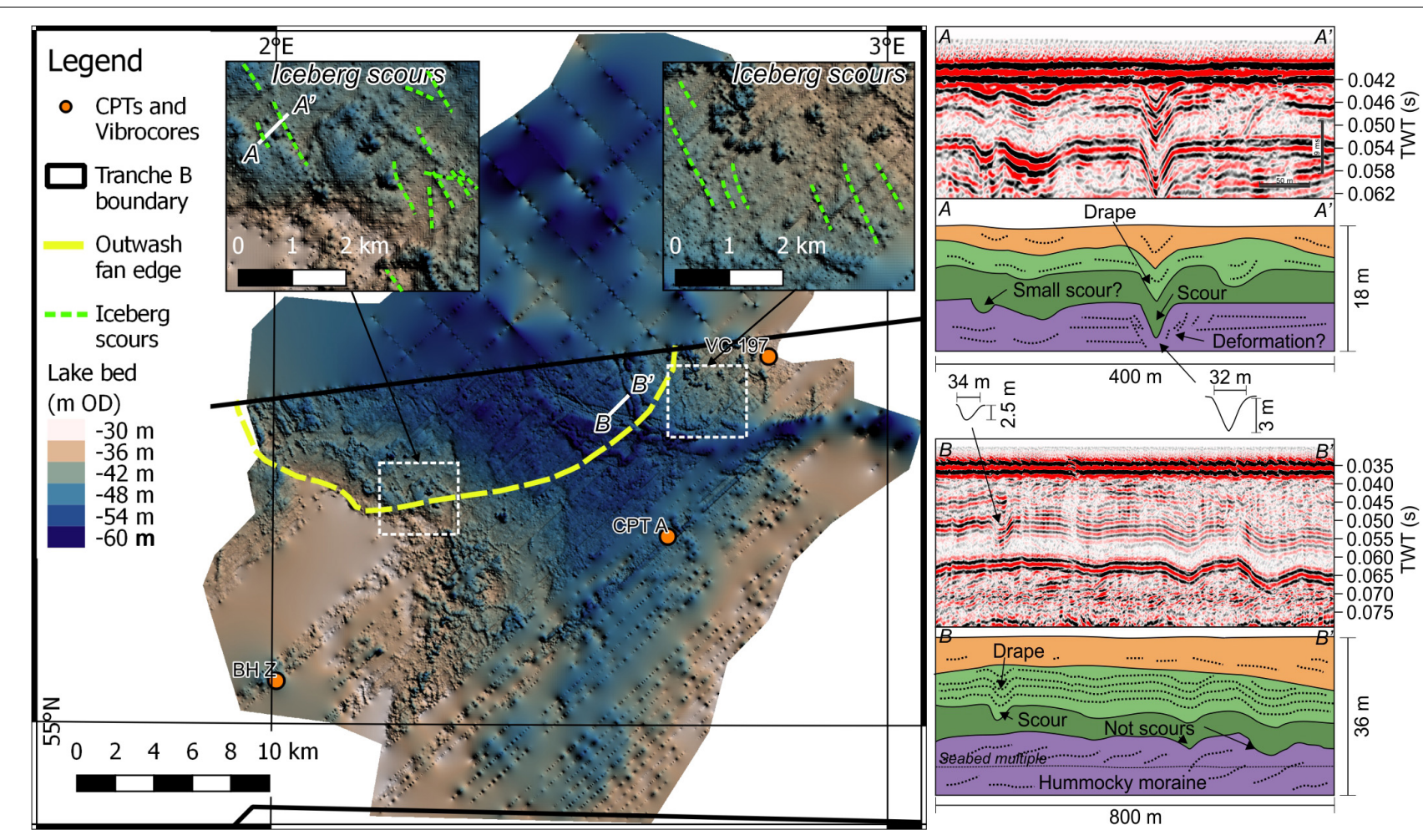

FIGURE 7 | Map of the proglacial lake bed showing its morphology and the presence of iceberg scours. Seismic sections show morphology of iceberg scours as well as lake-bed topography that may appear to be scours in map form. The location of ice-rafted debris found in CPT A is shown. Color bar "La Paz" from Crameri (2018).

The lake bed surface onto which the Lower and Upper Lake Dogger sub-units were deposited shows a series of concave-up lineations (Figure 7). These features generally strike NNW-SSE and range in length from 400 to $1000 \mathrm{~m}$. They are generally less than $100 \mathrm{~m}$ wide, with most being 10 to $30 \mathrm{~m}$. Their depth varies from 1 to $3 \mathrm{~m}$ (Figure 7). The lineations occur at elevations below $-38 \mathrm{~m}$ OD. Seismic sections through the lineations confirm they truncate the substrate, and also show some evidence for deformation of the substrate such as faulting immediately adjacent to the lineations (Figure 7). These features are interpreted to be iceberg scours. The iceberg scours are similar in dimension to many of those collated by Eden and Eyles (2001), especially those with similar water depths to those expected in Lake Dogger (e.g., Wahlgren, 1979; Dredge, 1982; Thomas and Connell, 1985; Eyles and Clark, 1988; Longva and Bakkejord, 1990). Deformation of soft sediments surrounding the lineations due to the iceberg keel pushing fine-grained sediments is also diagnostic of iceberg scouring (Woodworth-Lynas and Guigné, 1990; Linch et al., 2012; Linch and van der Meer, 2015).

\section{Depositional Environments}

Depositional environments are interpreted from correlation of sedimentary facies to the seismic units. Borehole samples were calibrated to CPT logs and seismic reflection data (Figure 3). Further correlation of sedimentary facies to seismic facies was provided by continuous vibrocores.

\section{Pre-LGM Substrate}

Few boreholes in the study area reach the pre-LGM substrate (Figure 3). A layer of clean very fine sand with large shell fragments at $\sim 50 \mathrm{~m}$ depth in a borehole at the south of Tranche B may represent a pre-LGM shelly lag in shallow marine sand (Cotterill et al., 2017a). Seismic reflections show very large ( $>5 \mathrm{~km}$ in width, and up to $200 \mathrm{~m}$ deep) channelfills incised into previous deposits. The top of these channelfills lie below the sand, and are interpreted to be either tunnel-valley fills or a proglacial drainage network, most likely formed by the thick, extensive Elsterian (MIS 12) ice sheet (Cotterill et al., 2017a). The sequence underlying the Dogger Bank Formation throughout Tranche B is therefore likely to comprise marine interglacial deposits of sands and gravelly sands with some silt and clay, all with abundant shells, belonging to the Eem, Cleaver Bank and Egmond Ground formations (Cotterill et al., 2017a).

\section{Subglacial and Glaciotectonised Sediments (Lower Sub-Unit of the Dogger Bank Formation)}

Seismic unit SU-A calibrates to two lithofacies observed in vibrocores and boreholes, a matrix-supported diamict (Dmm) and a massive silty clay (Fm). Both lithofacies are dense and overconsolidated (Figure 2). The diamict contains shell fragments and gravel of mixed lithology as well as sand inclusions that indicate incorporation of frozen sediments. Because of 
the incorporation of sand inclusions, the diamict is interpreted to be a glaciotectonite. The massive clay also contains shell fragments and occasional fine gravel of mixed lithology. Planes with slickensides within the massive clay observed in the western sector of the study area imply brittle deformation, probably due to glaciotectonics. The massive clay is interpreted to be a subglacial till (Evans et al., 2006).

Internally, the ridge morphology of SU-A contains evidence for deformation of the sediment. Serrate reflectors are interpreted to be chevron folds (Figure 4). Thrust faulting is also observed within the ridge morphology (Figure 4). The structural domains are similar to those observed in Dogger Bank moraines to the west of the study area (Phillips et al., 2018). The chevron folds belong to structural domain 3 and the inclined, verging reflectors belong to structural domain 5 of Phillips et al. (2018). Because of its lithology, depositional environment and deformation, as well as its proximity and similar stratigraphic context to those moraines observed by Phillips et al. (2018), this seismic unit and correlated subglacial till and glaciotectonite is assigned to of the Lower Dogger Bank sub-unit of the Dogger Bank Formation.

\section{Subaerial Glacial Outwash (Upper Sub-Unit of the Dogger Bank Formation)}

Seismic unit-B unconformably overlies and downlaps onto SUA, and comprises mainly variable and transparent (see Table 2 for description) seismic facies (Figures 3, 4). When calibrated to borehole samples and CPTs (Figure 4), these seismic units comprise the clast-supported gravel $(\mathrm{Gm})$ and the interbedded sands, silts and silty clay (Sl/Fl) lithofacies (Figure 2). The grain sizes are generally coarser than those observed in the Lower Dogger Bank sub-unit, as shown on CPT logs (Figure 4). Both lithofacies are overconsolidated on CPT logs (Figure 2). The mixed grain sizes and interbedded nature of the sediments implies that these sediments were deposited in a mixed-energy environment. Overconsolidation of the lithofacies implies the sediments were overridden by ice or exposed subaerially, allowing for desiccation. Because of their stratigraphic position above subglacial and glaciotectonised sediments, and their lithofacies differences, desiccation is inferred to be the process responsible for the overconsolidation. The presence of shell fragments and clasts of mixed lithology imply reworking of marine sediments as well as clastic input from a varied catchment, as observed in similar formations by Cotterill et al. (2017a). This depositional environment is interpreted to be glacial outwash, deposited subaerially from sediment-laden sub- and englacial meltwater at the retreating ice-sheet margin. The thickness of the Upper subunit of the Dogger Bank Formation varies across the study area. In the eastern sector, its thickness varies from absent, up to a maximum of $10 \mathrm{~m}$. In the western sector of the study area, it is much thicker, between 15 and $30 \mathrm{~m}$ thick (Figure 3).

\section{Proglacial Lake Sediments (Botney Cut Formation)}

In the eastern sector of the study area, three seismic units (SU-C, SU-D, and SU-E) fill a large basin formed between the elongate ridges of glaciotectonised sediments of SU-A, and large accumulations of outwash of SU-B (Figure 4).

\section{Basal proglacial lake fill (Basal Lake Dogger sub-unit)}

The first unit deposited in the basin fill, seismic unit SU$\mathrm{C}$, onlaps onto previous deposits and comprises a mixture of oblique tangential and transparent seismic facies (Figure 5). No vibrocores or boreholes penetrate $\mathrm{SU}-\mathrm{C}$, but a generally low cone resistance from CPT logs implies interbedded clay and silt (Figure 3). The oblique tangential reflectors imply a fan delta prograding into the lake basin. At least three packages of oblique tangential reflectors exist, with delta topsets at different elevations, implying a relative, stepped lake level rise. The top reflector of SU-C is high amplitude and horizontal (Figure 5), possibly suggesting that lake basin accommodation was filled, or that meltwater and sediment supply to the lake stopped. Downlapping and draping of the overlying seismic units onto the top surface imply a gap in the depositional record (Figure 5). The high amplitude reflector is interpreted to represent overconsolidation, either through ice margin readvance or desiccation. As no deformation related to ice-marginal oscillation is observed, subaerial exposure likely led to desiccation of the initial lake fill, as observed in other subaerially exposed units on Dogger Bank (Cotterill et al., 2017a,b) and in other lake-fills observed in seismic data in the geological record (D’Agostino et al., 2002).

\section{Ice-contact proglacial lake fill (Lower Lake Dogger sub-unit)}

The lobate, downlapping, southwest-thinning transparent SU$\mathrm{D}$ corresponds to clay-rich responses from CPTs, but are not penetrated by vibrocores or borehole samples (Figure 3). Patchy, inclined, and locally folded reflectors imply small-scale, localized deformation that is interpreted as slumping due to gravitational instability (Figure 5). Due to its lobate shape (Figure 5), finegrained sediments and slumping, SU-D is interpreted to be an icecontact subaqueous outwash fan, with finer-grained sediments in the distal part of the fan. Commonly, the base of SU-D and the onlapping seismic unit of SU-E contains a laminated silt to fine sand layer with subangular to rounded gravel of lithofacies $\mathrm{Sh}(\mathrm{d})$ and clasts of clay (Figures 2, 3). This thin $(<50 \mathrm{~cm})$ layer of coarser sediments is interpreted to be ice-rafted debris (IRD) on the basis of the presence of oversized clasts of mixed lithology and clay till pellets within laminated lake sediments (Thomas and Connell, 1985; Cowan et al., 2012). These sediments were carried out to the distal parts of the lake by floating icebergs calved from the glacier margin, as opposed to transport within the lake water.

\section{Ice-distal proglacial lake fill (Upper Lake Dogger sub-unit)}

The youngest proglacial lake unit comprises characteristic high frequency, medium-amplitude, continuous seismic reflectors (SU-E) that are draped above, and are parallel to, the lake bed. Laterally, the reflectors onlap onto the ice-contact lake fill and the subglacial and glacial outwash (Figure 5). In vibrocore and borehole, this seismic unit corresponds to the finely laminated silts and clays (lithofacies Flv). The laminae pairs alternate between pale silt and dark clay with sharp contacts. Where very fine sand is present, it occurs at the base of the pale silty unit and is normally graded. Because of the silt-clay pairs and the normally graded silt laminae (Figure 2), the lithofacies is interpreted to be a siliciclastic varve sequence (Zolitschka, 2007). The fine-grained 
deposits imply quiet-water conditions during their deposition. The low-energy rhythmites that are draped parallel with the lake bed could be interpreted as overflow-interflow dispersal of sediments within the lake that is typical of proglacial lakes distal to the ice margin (Smith and Ashley, 1985; Carrivick and Tweed, 2013). Therefore, it is interpreted that this uppermost unit of the Lake Dogger sub-unit was deposited at a time when the ice margin was further to the northwest, not in contact.

\section{Postglacial}

Two depositional environments are grouped together. Channel forms with high-amplitude fill calibrate to interbedded sands and clays with organic matter [lithofacies $\mathrm{Sl}(\mathrm{o}) / \mathrm{Fl}(\mathrm{o})]$. The interbedded nature of sands and clays of the channel-fills imply a fluvial depositional environment, with accumulation of organic matter washed in from the surrounding tundra plain (Cotterill et al., 2017a). One large, east-west orientated channel (Figure 3) with a high-amplitude fill may be related to an earlier channel that allowed lake drainage. However, the highamplitude fill destroys any signal from below the channel, and its stratigraphic relationship to the proglacial lake sediments cannot be determined.

On top of, and in places partially filling, the channel network is clean, well sorted, bioturbated sand (lithofacies Sm) with abundant shells and shell fragments (Figure 2). This represents the transition to a fully marine depositional environment as documented by Emery et al. (2019). The shallow marine sand cover varies in thickness throughout the study area from absent to up to $13 \mathrm{~m}$ in the southeast of the study area (see Figure 3 in Cotterill et al., 2017a). Sigmoidal reflectors within the shallow marine sand are interpreted to show progradation of the sand from west to east (Figure 3).

\section{DISCUSSION}

\section{Paleogeographic Evolution of Southeastern Dogger Bank}

The sedimentological, seismic stratigraphic and geomorphic observations are combined to present a conceptual, six-stage model of ice sheet advance and retreat, and landscape evolution on the southeastern edge of Dogger Bank (Figure 8).

\section{Stage One: Ice Sheet Advance to Maximum Extent}

The preserved landform assemblage in the eastern sector of the study area comprises a complex network of subglacial bedforms, meltwater channels, eskers, hummocky moraines, and a single thrust-block moraine complex at the same stratigraphic level (Figures 4, 6). The subglacial landforms are located to the northwest of the hummocky moraines, which in turn are located to the northwest of the thrust-block moraine complex (Figure 4). Streamlined subglacial bedforms of this scale imply warm-based ice and fast ice flow with low bed shear stresses (Stokes and Clark, 1999; Jamieson et al., 2016). The subglacial landforms and streamlined bedforms form a corridor, orientated northwestsoutheast, which is at least $15 \mathrm{~km}$ wide (Figure 6) that occupies the eastern sector of the study area. Because of the warm-based, fast ice flow with a streamlined corridor of subglacial landforms, the eastern sector of the study area is interpreted to have been formed by an ice stream (Stokes and Clark, 1999, 2001; Evans et al., 2008). Furthermore, this landform assemblage conforms to a surging ice-stream landsystem (Evans and Rea, 1999; Evans et al., 2014). In this situation, ice flows rapidly to its maximum extent, forms a thrust-block moraine complex, then shuts down and stagnates, resulting in an isochronous (or near-synchronous) imprint of an ice stream in the sedimentary archive (Stokes and Clark, 1999; Stokes, 2018).

The main control invoked on ice-stream location is topographic focusing (Winsborrow et al., 2010). However, in the North Sea Basin, relief is low, therefore topography is not inferred to be the only influence. Subglacial meltwater routing can control the location of an ice stream (Winsborrow et al., 2010). Dendritic meltwater channels and a braided esker network imply efficient, channelized drainage of large volumes of meltwater (Röthlisberger, 1972; Auton, 1992; Greenwood et al., 2007, 2016a; Storrar et al., 2014b). The implication of this well-ordered drainage is that meltwater was at low pressure during the formation of this drainage network (Greenwood et al., 2016a), which may imply high basal shear stress due to high effective stress at the base of the ice sheet. This is at odds with high-pressure fluids usually inferred to be associated with fast ice flow (Engelhardt et al., 1990; Wellner et al., 2006; Peters et al., 2007; Greenwood et al., 2016a; Stearns and van der Veen, 2018). It is therefore likely that a time-transgressive subglacial hydrological imprint was left on the subglacial bed, and we suggest low-pressure, dendritic channels formed close to the ice-sheet margin during ice advance, which then controlled the location of ice streaming with higher meltwater pressures and bed shear stress.

In the western sector of the study area, a different landform assemblage is observed (Figures 4, 6). No streamlined subglacial bedforms, eskers or hummocky moraine are present, and the relatively sparse subglacial meltwater channel network is strongly non-dendritic and anastomosing, with abrupt channel terminations (Figure 6). This implies an inefficient drainage of high-pressure fluid in a canal network (Greenwood et al., 2016a), often observed with deformable beds (Walder and Fowler, 1994). The relative lack of meltwater influence at the bed implies englacial meltwater transport, with fluid pressures near that of ice pressure. This allowed cold-based ice to dominate, resulting in higher shear stresses within the deforming sediment and the formation of brittle deformation features, such as shear planes and faults (Szuman et al., 2013) as observed from subglacial diamicts in borehole BH B (Figure 2). The lack of bedforms suggests a slower ice flow (Punkari, 1997b; Szuman et al., 2013; Stokes, 2018), or that bedforms have been reworked during active ice-margin retreat. However, the subglacial meltwater channels have been preserved, favoring the interpretations of slower, interstream ice-sheet flow.

The southern limit of ice in the North Sea at the LGM is poorly constrained due to a lack of data, leading to several competing hypotheses (Phillips et al., 2017b). Previous authors have interpreted that the ice sheet stopped to the north and west of Dogger Bank (e.g., Cameron et al., 1992), or overrode 

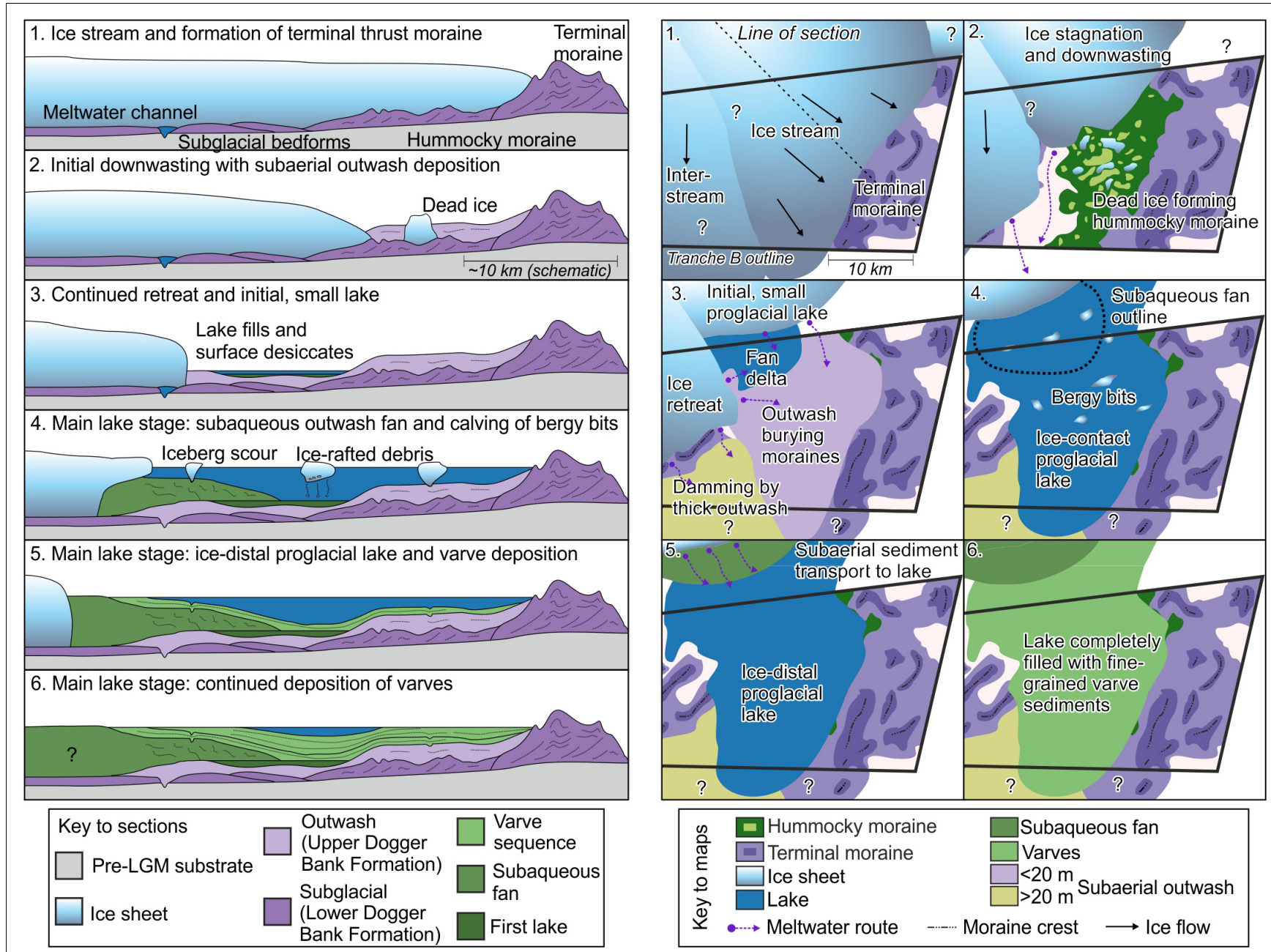

FIGURE 8 | Conceptual landscape evolution model during ice-sheet retreat in the study area. Schematic cross-section stages show stratigraphic evolution of the ice stream and proglacial lake. Paleogeographic maps show the spatial landscape evolution and lateral changes in ice sheet margin. Numbers correspond to stages described in section "Paleogeographic Evolution of Southeastern Dogger Bank."

Dogger Bank entirely, varying by up to $200 \mathrm{~km}$ in places (e.g., Sejrup et al., 2005, 2016; Carr et al., 2006; Phillips et al., 2018; Roberts et al., 2018). No precise limit can be seen within the study area as the terminal moraines extend to the south and west (Figure 4). However, an inference can be made based on the Dogger Bank Formation abruptly thinning toward the southeastern corner of the study area (Figure 4) which suggests that this was the terminal position of the ice sheet during the Last Glacial Maximum. An alternative interpretation that the thinning is due to erosion can be ruled out because the reflectors within the Upper and Lower sub-units of the Dogger Bank Formation are not truncated at their top surfaces (Figure 4). The flat bathymetry of Oyster Ground, to the southeast of Dogger Bank (Figure 1), lacks any evidence for glacial advance such as terminal moraines. The thickening Late Holocene sand wedge on the southern edge of Dogger Bank imply that this shallowest point of Dogger Bank is a more recent feature than an MIS 2 ice sheet extent (Figure 1; Emery et al., 2019). Because of these constraints, it is inferred that the ice sheet did not extend beyond the southern margin of Dogger Bank, in contrast to previous estimates (Hughes et al., 2016; Sejrup et al., 2016; Cotterill et al., 2017a; Phillips et al., 2018), but reached a limit just to the north of the break in the southern slope of today's Dogger Bank (Figure 9). The juxtaposition of different ice flow velocities is interpreted in many lobate-margined, lowland-terminating ice sheets in the geological record (Punkari, 1995, 1997a,b; Evans and Rea, 1999; Evans et al., 2008, 2014, 2016b; Szuman et al., 2013; Darvill et al., 2014; Margold et al., 2015, 2018; Stokes et al., 2015; Larsen et al., 2016; Phillips et al., 2017a). The ice stream and interstream areas identified in this study may have resulted in a more lobate margin than presented in Figure 9. Further constraint on the actual character of the ice-sheet margin in the North Sea is limited due to a lack of high-resolution seismic reflection data.

Subglacial topography revealed through interpretation of regional BGS seismic surveys (Figure 10) shows that Dogger Bank was a topographic high prior to the LGM, formed due 


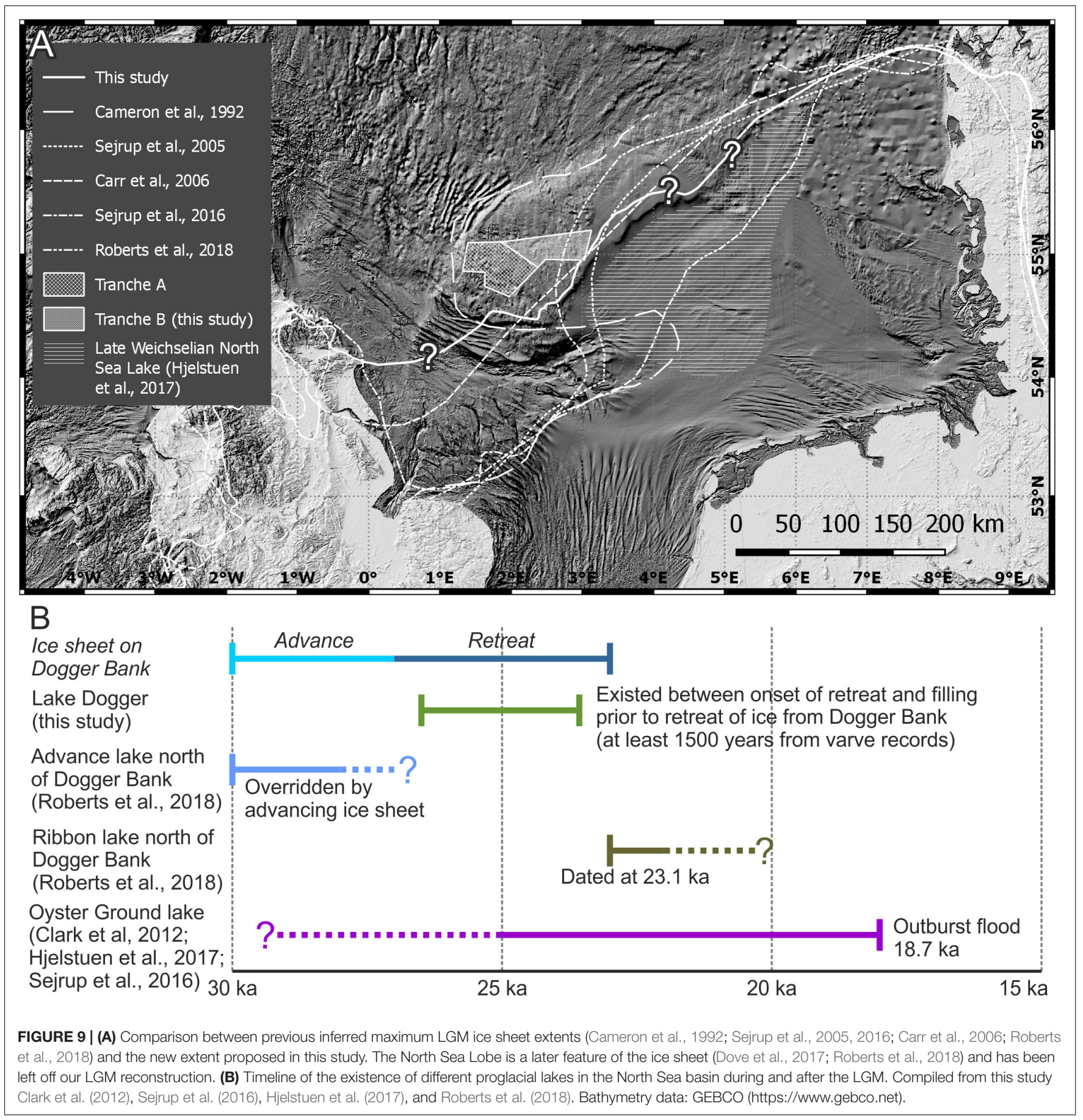

to the northward progradation of shallow marine sands into open waters (Cameron et al., 1992; Cotterill et al., 2017a). This would have provided an inverse, north-dipping gradient for the advancing, thin ice sheet to climb, potentially explaining why the ice sheet did not reach any further than the southern margin of Dogger Bank. Geothermal heat-flow density at Dogger Bank is also low, potentially causing a sticking point and arresting any further southerly progress of the rapidly advancing ice sheet (Hurtig, 1995; Hurter and Haenel, 2002;
Doornenbal and Stevenson, 2010). This opposite geothermal effect is observed at the southern margin of the Scandinavian Ice Sheet in the Wielkopolska Lowlands, where a higher geothermal heat flux than the surrounding area increased ice velocity and flow (Szuman et al., 2013, 2018).

The presence of a large proglacial lake, distinct from that identified in this study, which occupied Oyster Ground (Figure 1) during MIS 2 has been debated (Figure 9; Toucanne et al., 2010; Clark et al., 2012; Murton and Murton, 2012; Sejrup et al., 2016; 


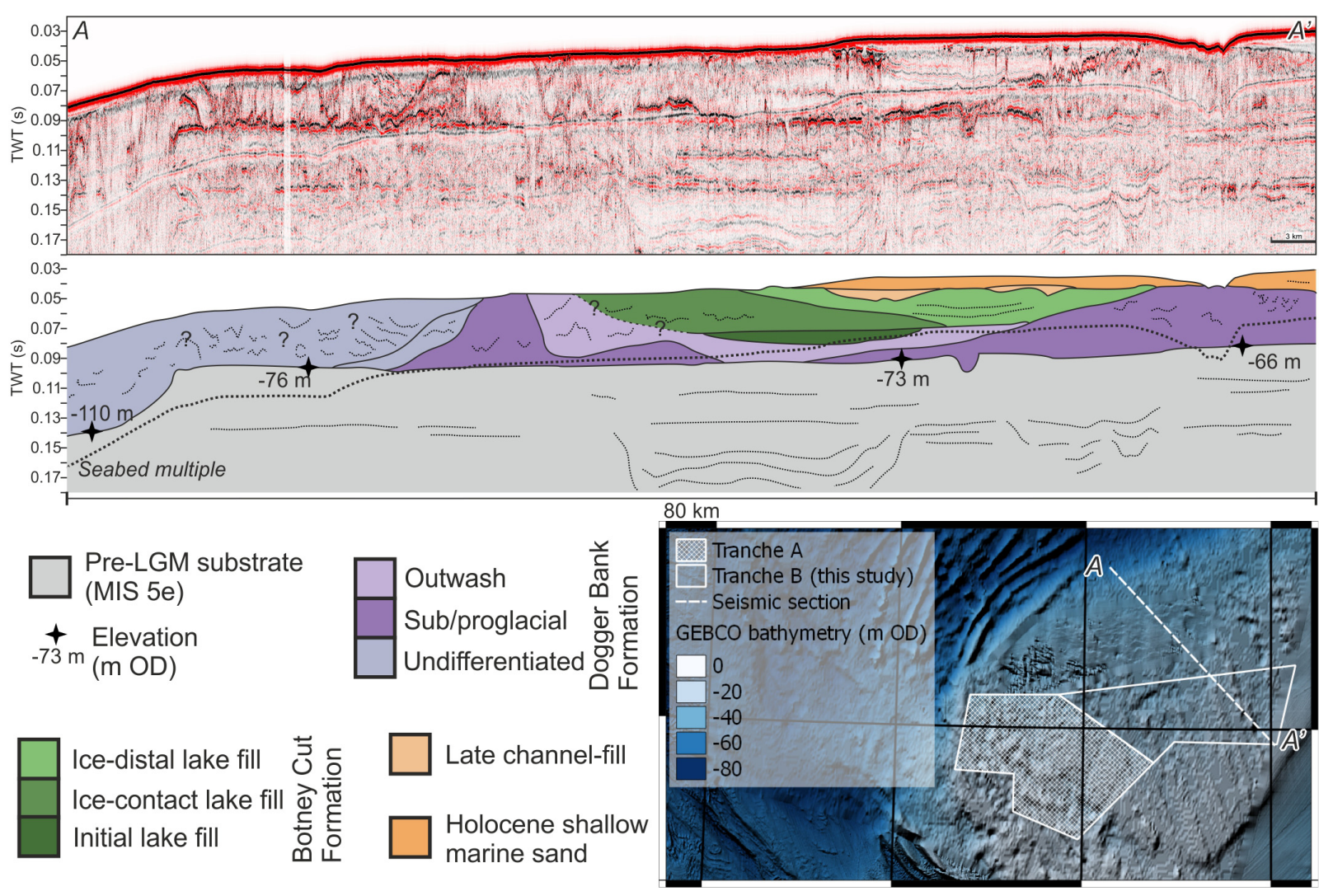

FIGURE 10 | British Geological Survey regional seismic section through Dogger Bank showing the subglacial topography toward the northern slope of Dogger Bank. Elevation of the subglacial surface deepens to the northwest and is echoed in the present-day bathymetry. No detailed seismic investigation of the northern slopes of Dogger Bank has yet been undertaken. Bathymetry data: GEBCO (https://www.gebco.net).

Hjelstuen et al., 2017; Roberts et al., 2018). If the ice stream terminated in a lake, a narrow terminal zone would result in calving and no moraine (Boyce and Eyles, 1991; Stokes and Clark, 2001), and the presence of geomorphologically distinct grounding zone wedges (Powell, 1984; McCabe and Eyles, 1988; Powell and Alley, 1997; Dowdeswell and Fugelli, 2012). However, the ice stream in the study area conforms to a land-terminating terrestrial ice-stream because of the presence of the large terminal thrust-block moraine complex (Patterson, 1997; Stokes and Clark, 2001). It is possible that ice advanced into a lake beyond the interpreted terminal thrust-block moraine complex, but no suitable data exist to the southwest of the study area to test this. It seems unlikely that this particular ice stream was laketerminating when considering the preserved landforms and the lack of evidence for further southward advance beyond Dogger Bank from bathymetry data.

\section{Stage Two: Ice Stream Shutdown and Ice Margin Retreat}

Hummocky moraine observed in the study area formed as the ice stream shut down and began to stagnate, with dead ice pressing and deforming the clay-rich Lower sub-unit of the Dogger Bank Formation subglacial till (Evans and Rea, 1999; Eyles et al., 1999; Boone and Eyles, 2001). An alternative explanation for the hummocky topography is meltwater runoff and mass-wasting events from the side of larger landforms. However, the hummocky topography shows no evidence for meltwater channels, and the relief underneath the hummocky moraine is close to horizontal, implying no mass wasting could occur (Figure 4). Ice stagnation preserved the subglacial bedforms, meltwater channels, and eskers, as the ice downwasted and retreated rapidly without reworking. In addition to the preservation of the subglacial landforms, no evidence of ice sheet readvance, such as overriding or reworking of landforms and subglacial till deposition, is seen in the east of the study area, implying the formation of the thrust-block moraine complex and subsequent retreat was a single advance and retreat event, at least in this location. A single, rapid phase of retreat of the ice stream contrasts with observations from Tranche A of the Forewind area (Cotterill et al., 2017b; Phillips et al., 2018), where intense reworking and multiple moraine ridges are a time-transgressive imprint of the ice margin (Stokes and Clark, 1999), formed under active retreat (Figure 11). A stepped ice-sheet retreat in Tranche A, with reworking of previous deposits is shown by at least four retreat moraine ridges. The ice margin in Tranche $\mathrm{A}$ is interpreted to represent a cold-based interstream, between ice streams, that deglaciated more slowly. Basal conditions in the ice sheet appear to be the main control of the style 
and rate of ice sheet retreat. Due to the high fluid pressures and coupling between the ice sheet bed and the substrate, intense, brittle-dominated glaciotectonic deformation resulted from oscillations of the ice sheet margin (Phillips et al., 2017a, 2018). Therefore, each fluctuation of mass balance during icesheet retreat may have resulted in formation of retreat moraines.

In the eastern sector of the study area, only a thin (typically $<5 \mathrm{~m}$ ) layer of Upper sub-unit of the Dogger Bank Formation outwash sediments are present between the Lower sub-unit of the Dogger Bank Formation and the lake bed (Figures 3, 5), which drapes inherited subglacial topography (Figure 8). A source of the outwash drape is englacial sediment entrained within the ice sheet during advance over soft substrate (Alley et al., 1997). However, the abundance of meltwater under the ice stream resulted in reduced ability to entrain subglacial sediment. The relatively thin outwash in the eastern sector of the study area contrasts with the thick outwash in the interstream area. The cold-based interstream ice allowed greater amounts of sediment entrainment through adfreezing and supercooling (Alley et al., 1997; Christoffersen and Tulaczyk, 2003), which was then transported englacially to the ice sheet margin. This explains the significant accumulations of outwash in the interstream lobe area (Figure 3).

\section{Stage Three: Initial Lake Formation}

During this stage of retreat, a relatively small proglacial lake $\left(\sim 90 \mathrm{~km}^{2}\right)$ formed in a shallow basin within the outwash sediments (Figure 8). Proglacial deposition of the Basal Lake Dogger sub-unit is recorded in three levels of fan deltas prograding and backstepping toward the northwest. The first of these deltas is in the southeast of the initial lake basin, and delta transgression occurred in a northwesterly direction. The flat, high-amplitude reflector at the top of this depositional unit (Figure 5) implies a period of subaerial exposure and desiccation, either due to accommodation filling, or due to a lake drainage event. This period of subaerial exposure implies that during this stage, no large lake formed (Figure 8), which implies that there was either not sufficient damming of meltwater or an insufficient supply of meltwater to the basin. Inferred ice stagnation, combined with continued supply from the margin inferred from the presence of eskers, implies that meltwater supply was plentiful during this stage, therefore it seems more likely the dam must have been incomplete to allow drainage. The thrust-block moraine complex forms a continuous dam to the south and east, implying that the meltwater was able to drain through a gap to the west.

\section{Stage Four: Large Ice-Contact Proglacial Lake}

A larger dam must have formed to allow the formation of a larger proglacial lake with a higher lake level, up to at least $-26 \mathrm{~m}$ OD (Figure 5). The gap in the west was plugged, either by a separate ice lobe readvance, or by accumulation of a thick sequence of outwash sediments from an adjacent ice lobe (Figure 8). In the western sector of the study area, subaerial outwash is up to $30 \mathrm{~m}$ thick (Figure 3), implying a significant accumulation of these sediments during retreat of the interstream ice-sheet margin. The presence of the lake for an extended period of time, along with the drape of proglacial lake sediments on top of subaerial outwash, suggests that the accumulation of outwash sediment is responsible for completing the dam. These outwash sediments onlap onto the side of the thrust-block moraine complex in the south of the study area (Figure 4), forming a combined subaerial outwash and thrust-block moraine dam. This combined outwash-head and terminal moraine dam is commonly observed in New Zealand and Icelandic proglacial lakes (e.g., Lake Pukaki and Lake Oahu, Sutherland et al., 2019; Heinabergsjökull, Evans and Orton, 2015). In these lakes, the outwash heads are a sign of sediment-laden meltwater exiting across the ice-sheet margin at many points, allowing outwash fans to build. This supports the interpretation of outwash sediments deposited from an adjacent lobe of the ice sheet that was still in the process of retreating (Figure 8).

Ice-rafted debris is found in borehole samples and iceberg scours are present on the lake bed (Figure 7), and the presence of floating ice in the lake is diagnostic of a calving ice-sheet margin (Smith and Ashley, 1985; Thomas and Connell, 1985; Carrivick and Tweed, 2013; Sutherland et al., 2019). The lobate geometry and downlapping stratal terminations of the Lower Lake Dogger sub-unit (Figure 5) imply a subaqueous outwash fan, with sediment-laden subglacial meltwater plumes fed from subglacial conduits flowing into the lake and depositing the fan, which has then been subject to localized gravitational collapse. The lobate shape of the Lower Lake Dogger sub-unit suggests that sediment was supplied at a velocity or concentration that it settled out of suspension close to the meltwater source, as opposed to being distributed by overflows or interflows (Smith and Ashley, 1985; Carrivick and Tweed, 2013). Increases in stress at the margin due to contact with the lake would have driven an increase in ablation due to iceberg calving, leading to rapid ice-sheet retreat (Benn et al., 2007).

\section{Stage Five: Large Ice-Distal Proglacial Lake}

Continued ice-sheet retreat caused the isolation of the proglacial lake from the ice-sheet margin (Figure 8). There is no direct evidence within the study area for why the lake became cut off from the ice sheet, but may have been due to lake-level fall or increase in outwash deposition. The rhythmic distribution of fine-grained sediments draped over lake-bed topography implies deposition of sediments in a low-energy, quiet-water lake (Figure 5). The draping of sediments implies the development of a strong thermocline within the lake, distributing sediments within the water column via overflows and interflows (Smith and Ashley, 1985; Carrivick and Tweed, 2013). The development of a strong thermocline suggests that the ice-sheet margin was not in contact with the lake as high sediment and cold meltwater supply associated with ice-margin contact prevent density stratification in proglacial lakes (Smith and Ashley, 1985; Carrivick and Tweed, 2013). Up to $30 \mathrm{~m}$ of varves accumulated during this time (Figure 1) implying a constant supply of sediment from the ice sheet to the lake for an extended period of time.

Combining varve thickness $(15-20 \mathrm{~mm})$ with the thickness of the succession $(30 \mathrm{~m})$ gives an estimate of 1500 to 2000 years of lake sedimentation. The lake must have received sedimentladen meltwater from a distal ice sheet for at least this period 


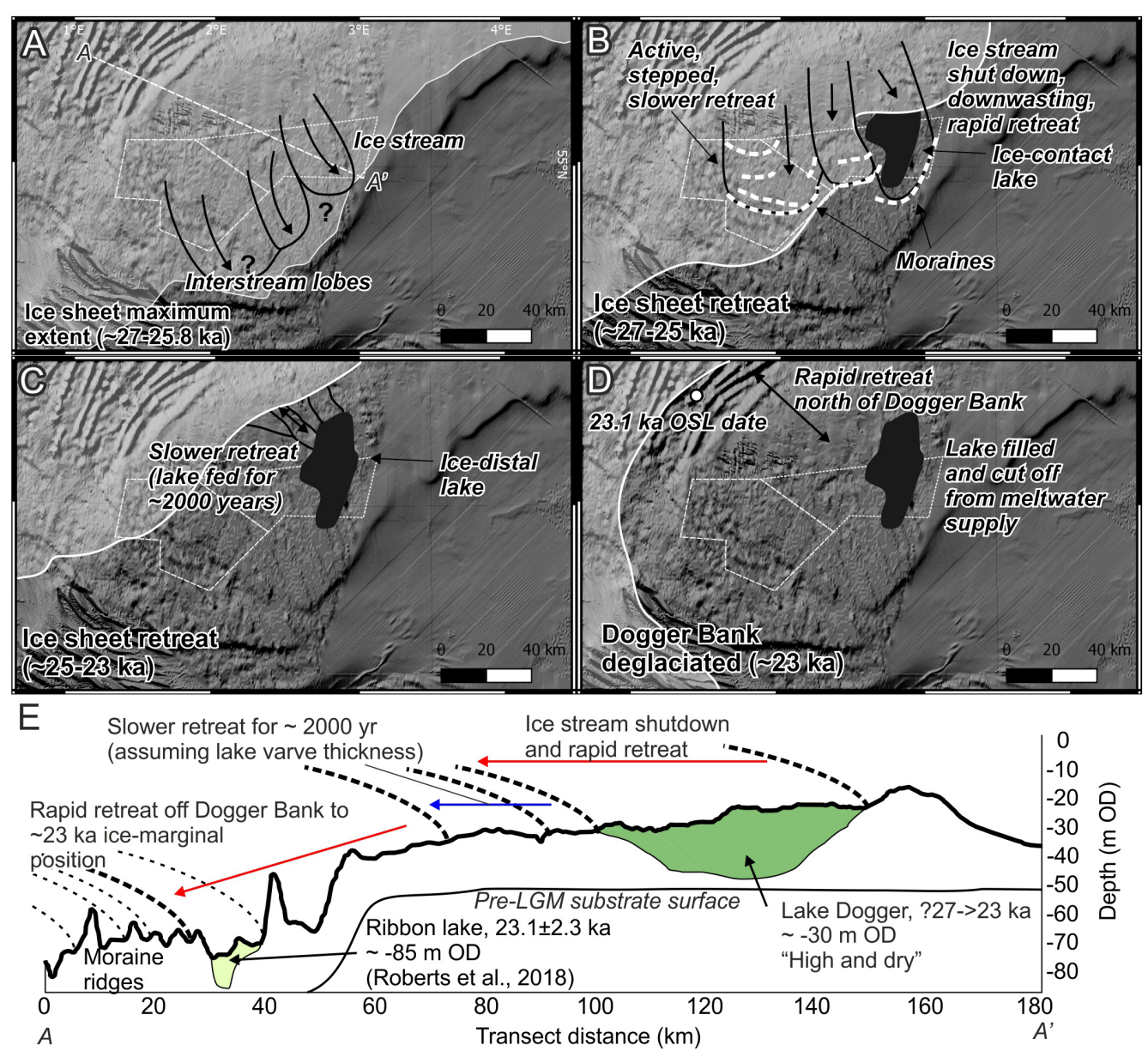

FIGURE 11 | Wider implications and approximate timing of observed ice-sheet retreat in the study area. (A) Ice at its maximum extent, showing the locations of possible ice streams and interstream lobes. The inferred lobate nature of the margin is shown schematically. (B) Initial ice-sheet retreat and ice-contact proglacial lake stage. Moraines in Tranche A are from Phillips et al. (2018). (C) Continued retreat and ice-distal proglacial lake stage, with postulated channels draining from the ice sheet into the lake. (D) Final rapid retreat off the northward-dipping inverse slope and isolation of the proglacial lake. The $23.1 \mathrm{ka}$ OSL date is from Roberts et al. (2018). (E) Bathymetry profile through Dogger Bank to the ribbon lake of Roberts et al. (2018) highlighting approximate ice-sheet retreat rates and the higher, older lake on top of Dogger Bank. Bathymetry data: GEBCO (https://www.gebco.net).

of time, implying a reduction in the rate of ice retreat prior to complete retreat off Dogger Bank. Ice reached its maximum extent at Dogger Bank between 27-25.8 ka BP (Clark et al., 2012; Hughes et al., 2016; Roberts et al., 2018) and had retreated north of Dogger Bank by 23.1 ka BP (Figure 11; Roberts et al., 2018). The intervening period of approximately 2.6 to $3.8 \mathrm{k}$ year is the duration of ice retreat over a distance of approximately $50 \mathrm{~km}$. An initial phase of rapid retreat due to ice stream stagnation and downwasting, with the margin retreating approximately 30$40 \mathrm{~km}$ during this phase, was followed by a slower phase of retreat, around $30 \mathrm{~km}$ in 1,500 to $2000 \mathrm{yr}$, before another rapid phase of retreat by around $20 \mathrm{~km}$ off Dogger Bank (Figure 11).

Subglacial topography was likely a control on the rate of retreat. As the ice sheet retreated northward, it encountered a southward-dipping topography, slowing the retreat rate and allowing subsequent varve deposition (Figure 11). A steeper and larger inverse (northward-dipping) slope at the northern margin of Dogger Bank resulted in a second rapid retreat phase (Figure 11). The magnitude of variability of subglacial topography beneath the retreating ice sheet is on the order of tens of meters. This relatively subtle topographic variability appears to have been sufficient to control the rate of retreat when combined with proglacial lake calving. The apparent control of subtle subglacial topography on rate of retreat suggests a thin ice sheet at its margin that was sensitive to subtle topographic changes.

\section{Stage Six: Lake Filling, Desiccation, and Subsequent Marine Transgression}

Overconsolidation of the lake sediments (Cotterill et al., 2017a) implies they were able to desiccate. Lake sediments reach elevations close to seabed of approximately $-26 \mathrm{~m}$ OD (Figure 3), implying that these significant accumulations of sediment filled the lake basin accommodation, forcing a change in sediment and meltwater routing to a channelized network flowing southward and eastward. Another option is that lake water was able to drain via a large channel that may exist 
running eastward from the lake. However, it is difficult to ascertain whether this was a single drainage event (e.g., Glacial Lake Outburst Flood, GLOF; Cotterill et al., 2017a), or whether draining was more protracted. It may also be possible that the channel is unrelated to the proglacial lake, as the acoustic blanking due to the high-amplitude fill within the channel makes it difficult to determine the stratigraphic relationship between the channel and lake sediments.

Subsequent erosion of channel forms seen in SU-Postglacial was followed by marine transgression and wave ravinement of some of the previous moraine and lake deposits (Emery et al., 2019). This was followed by deposition of shallow marine sands during the Holocene. The accumulation of glacial, outwash, proglacial lake, and shallow marine sediments at Dogger Bank result in a very different present-day bathymetry to the pre-glacial topography that the ice sheet advanced over. The discrepancy in pre- and post-glacial topographic surfaces may go some way to explain why models of ice sheet extent in the North Sea basin have currently been unable to recreate the extent interpreted from geomorphic evidence (e.g., Boulton and Hagdorn, 2006; Hubbard et al., 2009; Clason et al., 2014; Patton et al., 2016). The use of modern-day bathymetry as an input to previous models will inhibit a modeled ice stream initiating and flowing southward to the interpreted maximum extent. Future modeling of ice sheets in the North Sea basin should employ a reconstruction of subglacial topography based on seismic interpretation to rectify this situation.

\section{Implications for Offshore Engineering and Ground Models}

The detailed seismic interpretation undertaken in this study emphasizes the stratigraphic complexity, with many smaller seismic units, such as the subaqueous outwash fan, not being penetrated by boreholes, so no geotechnical information can be determined for these deposits. This highlights potential issues when identifying sites for wind turbines whose monopile footings may be up to $40 \mathrm{~m}$ deep with a diameter up to 7.5 or $10 \mathrm{~m}$, such as other offshore windfarms within the North Sea (Lesny and Wiemann, 2005; Cuéllar et al., 2012; Kallehave et al., 2015). The Horns Rev windfarm, offshore Denmark, for example, has monopile foundations $4 \mathrm{~m}$ wide and between 30 and $32.7 \mathrm{~m}$ deep (Augustesen et al., 2009). This depth at Dogger Bank may encounter many different sedimentary environments, with vibrocores showing up to seven depositional environments in less than $6 \mathrm{~m}$ of core in the southwest of the study area (Emery et al., 2019). Detailed seismic and stratigraphic mapping, and interpretation of sedimentary process and environments of deposition, integrated with geotechnical and lithological information, are therefore recommended to be an essential step in building a ground model during site investigation for offshore infrastructure. Cost-effective wind turbine placement relies on the detailed level of understanding of landscape evolution undertaken in this study.

The study highlights the unusual juxtaposition of a lakefill preserved perched on a topographic high (Figure 11). This phenomenon is recognized in hard-bedrock substrate settings in Greenland and Antarctica (Björck et al., 1996; Briner et al., 2010; Nedbalová et al., 2013; Carrivick et al., 2018), but not in soft sediment settings. Previous studies of proglacial lakes in the palaeo-record have identified lakes that are partially preserved in the stratigraphy in a present-day terrestrial setting, such as Glacial Lake Agassiz (Teller et al., 2002) or ice-marginal lakes of the Scandinavian Ice Sheet in northwest Russia (Lyså et al., 2011). Due to the unique location of Dogger Bank and its Holocene marine transgression, the lake sediments are well-preserved and their desiccated, overconsolidated nature has contributed toward their continued preservation. Such a lake being left "high and dry" on top of Dogger Bank raises the important point of superposition and elevation, whereby an older lake-fill is at a higher elevation than a younger lake-fill to the north (Figure 11; Roberts et al., 2018). This has implications for geotechnical properties due to the amount of time a lake bed may have been exposed subaerially and become desiccated and overconsolidated, prior to marine transgression, with further implications for costeffective wind turbine placement.

The transition to clean, renewable energy as a necessity for society is hugely dependent on cost-effective delivery of infrastructure such as offshore wind. It is therefore recommended that all offshore infrastructure would benefit from project development in conjunction with geologists seeking to understand the recent landscape evolution of our offshore areas. The added benefit of the insights gained into ice-sheet behavior, and its implications for projection of future sea-level rise, make such studies of great benefit to society.

\section{CONCLUSION}

Detailed investigation of a large, integrated dataset of vibrocores, geotechnical logs and a dense grid of 2D seismic reflection data has revealed a complicated glacial and proglacial stratigraphy at Dogger Bank. Above a pre-LGM substrate, a deformed subglacial and glaciotectonic unit is observed. After this, a subaerial outwash succession was deposited, followed by three stages of proglacial lake stratigraphy, before marine transgression during the Holocene.

Mapping of the subglacial and glaciotectonic surfaces has revealed a typical surging ice stream landsystem, which flowed from northwest to southeast. This ice stream shut down, stagnated and downwasted, causing rapid deglaciation. This left a basin for the proglacial lake to form, and allowed accumulation of proglacial lake sediments. The initial, small lake had limited accommodation, and so filled with sediment and desiccated before a much larger proglacial lake formed after damming by outwash sediments to the southwest. At first, this large lake was ice-contact, with deposition of a subaqueous outwash fan and iceberg calving resulting in scouring of the lake bed and distal deposition of ice-rafted debris. Continued rapid retreat, aided by iceberg calving, eventually separated the ice sheet margin from the proglacial lake. This allowed varve deposition in the quietwater, ice-distal lake. Approximately 1500-2000 years of varve deposition are recorded. This implies a slower rate of retreat 
whilst the ice sheet was still on Dogger Bank and able to feed sediment-laden meltwater to the lake. Final, rapid retreat of the ice sheet off Dogger Bank was aided by the inverse, north-dipping subglacial slope.

A refined maximum ice-sheet extent has been proposed for the North Sea during this time based on the geomorphological evidence presented. The large thrust-block moraine complex observed in the southeast corner of the study area is assumed to be terminal based on its scale and the lack of evidence for advance or readvance any further southeast of the moraine complex. Retreat from this maximum extent was controlled by basal conditions of the ice sheet. In the study area, initial ice sheet retreat was rapid due to the collapse of the warm-based ice stream. Because of the downwasting, little reworking of the previously deposited landforms and sediment occurred. This contrasts with observations from Tranche A to the west, where cold-based ice, associated with high-pressure fluids, record a slower, active ice sheet retreat. The rapid retreat in the study area is recorded in the proglacial lake stratigraphy and highlights the lobate nature of ice sheet margins and complexity of ice sheet retreat in the palaeo-record.

\section{DATA AVAILABILITY}

The datasets generated for this study will not be made publicly available because they belong to a confidential industry dataset. Requests to access the datasets should be directed to the corresponding author.

\section{REFERENCES}

Alley, R. B., Cuffey, K. M., Evenson, E. B., Strasser, J. C., Lawson, D. E., and Larson, G. J. (1997). How glaciers entrain and transport basal sediment: physical constraints. Quat. Sci. Rev. 16, 1017-1038. doi: 10.1016/S0277-3791(97) 00034-6

Augustesen, A. H., Brødbaek, K. T., Møller, M., Sørensen, S. P. H., Ibsen, L. B., Pedersen, T. S., et al. (2009). "Numerical modelling of large-diameter steel piles at horns rev," in Proceedings of the Twelfth International Conference on Civil, Structural and Environmental Engineering Computing, eds B. H. V. Topping, L. F. Costa Neves, and R. C. Barros, (Stirlingshire: Civil-Comp Press), 239. doi: $10.4203 /$ ccp. 91.239

Auton, C. A. (1992). Scottish landform examples - 6: the Flemington eskers. Scott. Geogr. Mag. 108, 190-196. doi: 10.1080/00369229218736865

Aylsworth, J. M., and Shilts, W. W. (1989). Bedforms of the Keewatin Ice Sheet. Canada. Sediment. Geol. 62, 407-428. doi: 10.1016/0037-0738(89) 90129-2

Ballantyne, C. K. (2010). Extent and deglacial chronology of the last British-Irish Ice Sheet: implications of exposure dating using cosmogenic isotopes. J. Quat. Sci. 25, 515-534. doi: 10.1002/jqs.1310

Banerjee, I., and McDonald, B. C. (1975). "Nature of Esker sedimentation," in Glaciofluvial and Glaciolacustrine Sedimentation, eds A. V. Jopling, and B. C. McDonald, (Tulsa, OK: Society for Sedimentary Geology), 132-154. doi: 10. 2110/pec.75.23.0132

Belt, T. (1874). An examination of the theories that have been proposed to account for the climate of the glacial period. Q. J. Sci. 4, 421-464.

Benn, D. I., and Evans, D. J. A. (2010). Glaciers \& Glaciation, 2nd Edn. London: Hodder Education.

Benn, D. I., Warren, C. R., and Mottram, R. H. (2007). Calving processes and the dynamics of calving glaciers. Earth Sci. Rev. 82, 143-179. doi: 10.1016/j. earscirev.2007.02.002

\section{AUTHOR CONTRIBUTIONS}

AE conducted the data analysis and interpretation, and wrote the manuscript, with significant support, contributions and improvements from all other authors.

\section{FUNDING}

This study was undertaken as part of a studentship funded by the Leeds Anniversary Research Scholarships. AE acknowledges the support of the Institute of Applied Geosciences at the University of Leeds, the Leeds for Life Foundation, the Quaternary Research Association INQUA Travel Fund, and the International Union for Quaternary Research INQUA Congress travel bursary for supporting earlier presentations of this work.

\section{ACKNOWLEDGMENTS}

The Forewind consortium and the British Geological Survey are thanked for provision of the data and permission to publish. CC and EP publish with permission of the Executive Director of the British Geological Survey. Professor David Roberts, Dr. Louise Callard, Dr. Claire Mellett, and Professor Brice Rea are thanked for their helpful discussions on the stratigraphy and palaeoglaciology of Dogger Bank. The reviewers, AG and NP, and the editor, BM, are thanked for their valuable input, which greatly improved the quality and clarity of this manuscript.

Björck, S., Olsson, S., Ellis-Evans, C., Håkansson, H., Humlum, O., and de Lirio, J. M. (1996). Late Holocene palaeoclimatic records from lake sediments on James Ross Island, Antarctica. Palaeogeogr. Palaeoclimatol. Palaeoecol. 121, 195-220. doi: 10.1016/0031-0182(95)00086-0

Boone, S. J., and Eyles, N. (2001). Geotechnical model for great plains hummocky moraine formed by till deformation below stagnant ice. Geomorphology 38, 109-124. doi: 10.1016/S0169-555X(00)00072-6

Boston, C. M., Evans, D. J. A., and Cofaigh, C. Ó (2010). Styles of till deposition at the margin of the Last Glacial Maximum North Sea lobe of the British-Irish Ice Sheet: an assessment based on geochemical properties of glacigenic deposits in eastern England. Quat. Sci. Rev. 29, 3184-3211. doi: 10.1016/j.quascirev.2010. 05.028

Boulton, G., and Hagdorn, M. (2006). Glaciology of the British Isles Ice Sheet during the last glacial cycle: form, flow, streams and lobes. Quat. Sci. Rev. 25, 3359-3390. doi: 10.1016/j.quascirev.2006.10.013

Boyce, J. I., and Eyles, N. (1991). Drumlins carved by deforming till streams below the Laurentide Ice Sheet. Geology 19, 787-790. doi: 10.1130/009176131991019<0787:DCBDTS<2.3.CO;2

Bradwell, T., and Stoker, M. S. (2015). Asymmetric ice-sheet retreat pattern around northern Scotland revealed by marine geophysical surveys. Earth Environ. Sci. Trans. R. Soc. Edinburgh 105, 297-322. doi: 10.1017/S1755691015000109

Bradwell, T., Stoker, M. S., Golledge, N. R., Wilson, C. K., Merritt, J. W., Long, D., et al. (2008). The northern sector of the last British Ice Sheet: maximum extent and demise. Earth Sci. Rev. 88, 207-226. doi: 10.1016/j.earscirev.2008.01.008

Bradwell, T., Stoker, M. S., and Larter, R. (2007). Geomorphological signature and flow dynamics of The Minch palaeo-ice stream, northwest Scotland. J. Quat. Sci. 22, 609-617. doi: 10.1002/jqs.1080

Briner, J. P., Stewart, H. A. M., Young, N. E., Philipps, W., and Losee, S. (2010). Using proglacial-threshold lakes to constrain fluctuations of the Jakobshavn Isbrae ice margin, western Greenland, during the Holocene. Quat. Sci. Rev. 29, 3861-3874. doi: 10.1016/j.quascirev.2010.09.005 
Callard, S. L., Cofaigh, C. Ó, Benetti, S., Chiverrell, R. C., Van Landeghem, K. J. J., Saher, M. H., et al. (2018). Extent and retreat history of the Barra Fan Ice Stream offshore western Scotland and northern Ireland during the last glaciation. Quat. Sci. Rev. 201, 280-302. doi: 10.1016/j.quascirev.2018.10.002

Cameron, T., Crosby, A., Balson, P., Jeffery, D. H., Lott, G. K., Bulat, J., et al. (1992). United Kingdom Offshore Regional Report: The Geology of the Southern North Sea. London: HMSO.

Carr, S. J., Holmes, R., van der Meer, J. J. M., and Rose, J. (2006). The Last Glacial Maximum in the North Sea Basin: micromorphological evidence of extensive glaciation. J. Quat. Sci. 21, 131-153. doi: 10.1002/jqs.950

Carrivick, J. L., and Tweed, F. S. (2013). Proglacial Lakes: character, behaviour and geological importance. Quat. Sci. Rev. 78, 34-52. doi: 10.1016/j.quascirev.2013. 07.028

Carrivick, J. L., Yde, J. C., Knudsen, N. T., and Kronborg, C. (2018). Ice-dammed lake and ice-margin evolution during the Holocene in the Kangerlussuaq area of west Greenland. Arctic Antarct. Alp. Res. 50:S100005. doi: 10.1080/15230430. 2017.1420854

Chiverrell, R. C., Smedley, R., Small, D., Ballantyne, C. K., Burke, M., Callard, S. L., et al. (2018). Ice margin oscillations during deglaciation of the northern Irish Sea basin. J. Quat. Sci. 33, 739-762. doi: 10.1002/jqs.3057

Christoffersen, P., and Tulaczyk, S. (2003). Response of subglacial sediments to basal freeze-on 1. Theory and comparison to observations from beneath the West Antarctic Ice Sheet. J. Geophys. Res. Solid Earth 108, 1-16. doi: 10.1029/ 2002jb001935

Clark, C. D., Ely, J. C., Greenwood, S. L., Hughes, A. L. C., Meehan, R., Barr, I. D., et al. (2018). BRITICE Glacial Map, version 2: a map and GIS database of glacial landforms of the last British-Irish Ice Sheet. Boreas 47:11-e8. doi: 10.1111/bor.12273

Clark, C. D., Evans, D. J. A., Khatwa, A., Bradwell, T., Jordan, C. J., Marsh, S. H., et al. (2004). Map and GIS database of glacial landforms and features related to the last British Ice Sheet. Boreas 33, 359-375. doi: 10.1111/j.1502-3885.2004. tb01246.x

Clark, C. D., Hughes, A. L. C., Greenwood, S. L., Jordan, C., and Sejrup, H. P. (2012). Pattern and timing of retreat of the last British-Irish Ice Sheet. Quat. Sci. Rev. 44, 112-146. doi: 10.1016/j.quascirev.2010.07.019

Clason, C. C., Applegate, P. J., and Holmlund, P. (2014). Modelling Late Weichselian evolution of the Eurasian ice sheets forced by surface meltwaterenhanced basal sliding. J. Glaciol. 60, 29-40. doi: 10.3189/2014JoG13J037

Cotterill, C. J., Phillips, E. R., James, L., Forsberg, C. F., Tjelta, T. I., Carter, G., et al. (2017a). The evolution of the Dogger Bank, North Sea: a complex history of terrestrial, glacial and marine environmental change. Quat. Sci. Rev. 171, 136-153. doi: 10.1016/j.quascirev.2017.07.006

Cotterill, C. J., Phillips, E. R., James, L., Forsberg, C. F., and Tjelta, T. I. (2017b). How understanding past landscapes might inform present-day site investigations: a case study from Dogger Bank, southern central North Sea. Near Surf. Geophys. 15, 403-413. doi: 10.3997/1873-0604.2017032

Cowan, E. A., Christoffersen, P., and Powell, R. D. (2012). Sedimentological signature of a deformable bed preserved beneath an ice stream in a late pleistocene glacial sequence, Ross Sea, Antarctica. J. Sediment. Res. 82, 270-282. doi: $10.2110 /$ jsr.2012.25

Crameri, F. (2018). Geodynamic diagnostics, scientific visualisation and StagLab 3.0. Geosci. Model Dev. 11, 2541-2562. doi: 10.5194/gmd-11-2541-018

Cuéllar, P., Georgi, S., Baeßler, M., and Rücker, W. (2012). On the quasi-static granular convective flow and sand densification around pile foundations under cyclic lateral loading. Granul. Matter 14, 11-25. doi: 10.1007/s10035-0110305-0

D’Agostino, K., Seltzer, G., Baker, P., Fritz, S., and Dunbar, R. (2002). Latequaternary lowstands of Lake Titicaca: evidence from high-resolution seismic data. Palaeogeogr. Palaeoclimatol. Palaeoecol. 179, 97-111. doi: 10.1016/S00310182(01)00411-4

Darvill, C. M., Stokes, C. R., Bentley, M. J., and Lovell, H. (2014). A glacial geomorphological map of the southernmost ice lobes of Patagonia: the Bahía Inútil - San Sebastián, Magellan, Otway, Skyring and Río Gallegos lobes. J. Maps 10, 500-520. doi: 10.1080/17445647.2014.890134

Davies, B. J., Roberts, D. H., Bridgland, D. R., Cofaigh, C. Ó, and Riding, J. B. (2011). Provenance and depositional environments of quaternary sediments from the western North Sea Basin. J. Quat. Sci. 26, 59-75. doi: 10.1002/jqs.1426
Delaney, C. A., McCarron, S., and Davis, S. (2018). Irish Ice Sheet dynamics during deglaciation of the central Irish Midlands: evidence of ice streaming and surging from airborne LiDAR. Geomorphology 306, 235-253. doi: 10.1016/j.geomorph. 2018.01.011

Doornenbal, H., and Stevenson, A. (2010). Petroleum Geological Atlas of the Southern Permian Basin. Houten: EAGE.

Dove, D., Evans, D. J. A., Lee, J. R., Roberts, D. H., Tappin, D. R., Mellett, C. L., et al. (2017). Phased occupation and retreat of the last British-Irish Ice Sheet in the southern North Sea; geomorphic and seismostratigraphic evidence of a dynamic ice lobe. Quat. Sci. Rev. 163, 114-134. doi: 10.1016/j.quascirev.2017. 03.006

Dowdeswell, J. A., and Fugelli, E. M. G. (2012). The seismic architecture and geometry of grounding-zone wedges formed at the marine margins of past ice sheets. Bull. Geol. Soc. Am. 124, 1750-1761. doi: 10.1130/B30628.1

Dowdeswell, J. A., and Ottesen, D. (2013). Buried iceberg ploughmarks in the early quaternary sediments of the central North Sea: a two-million year record of glacial influence from 3D seismic data. Mar. Geol. 344, 1-9. doi: 10.1016/j. margeo.2013.06.019

Dredge, L. A. (1982). Relict ice-scour marks and late phases of Lake Agassiz in Northernmost Manitoba. Can. J. Earth Sci. 19, 1079-1087. doi: 10.1139/ e82-089

Eden, D. J., and Eyles, N. (2001). Description and numerical model of Pleistocene iceberg scours and ice-keel turbated facies at Toronto, Canada. Sedimentology 48, 1079-1102. doi: 10.1046/j.1365-3091.2001.00409.x

Ehlers, J., and Wingfield, R. (1991). The extension of the Late Weichselian/Late Devensian ice sheets in the North Sea Basin. J. Quat. Sci. 6, 313-326. doi: 10.1002/jqs.3390060406

Ely, J. C., Clark, C. D., Spagnolo, M., Stokes, C. R., Greenwood, S. L., Hughes, A. L. C., et al. (2016). Do subglacial bedforms comprise a size and shape continuum? Geomorphology 257, 108-119. doi: 10.1016/j.geomorph.2016. 01.001

Emery, A. R., Hodgson, D. M., Barlow, N. L. M., Carrivick, J. L., Cotterill, C. J., Mellett, C. L., et al. (2019). Topographic and hydrodynamic controls on barrier retreat and preservation: an example from Dogger Bank, North Sea. Mar. Geol. 416:105981. doi: 10.1016/j.margeo.2019.105981

Engelhardt, H., Humphrey, N., Kamb, B., and Fahnestock, M. (1990). Physical conditions at the base of a fast moving glacier. Science 248, 57-59. doi: 10.1126/ science.248.4951.57

Evans, D. J. A., Bateman, M. D., Roberts, D. H., Medialdea, A., Hayes, L., Duller, G. A. T., et al. (2016a). Glacial Lake Pickering: stratigraphy and chronology of a proglacial lake dammed by the North Sea Lobe of the British-Irish Ice Sheet. J. Quat. Sci. 32, 295-310. doi: 10.1002/jqs.2833

Evans, D. J. A., Phillips, E. R., Hiemstra, J. F., and Auton, C. A. (2006). Subglacial till: Formation, sedimentary characteristics and classification. Earth-Science Rev. 78, 115-176. doi: 10.1016/j.earscirev.2006.04.001

Evans, D. J. A., Storrar, R. D., and Rea, B. R. (2016b). Crevasse-squeeze ridge corridors: diagnostic features of late-stage palaeo-ice stream activity. Geomorphology 258, 40-50. doi: 10.1016/j.geomorph.2016.01.017

Evans, D. J. A., and Benn, D. I. (2004). A Practical Guide to the Study of Glacial Sediments. London: Arnold.

Evans, D. J. A., Clark, C. D., and Rea, B. R. (2008). Landform and sediment imprints of fast glacier flow in the southwest Laurentide Ice Sheet. J. Quat. Sci. 23, 249-272. doi: 10.1002/jqs.1141

Evans, D. J. A., and Orton, C. (2015). Heinabergsjökull and Skalafellsjökull, Iceland: active temperate piedmont lobe and outwash head glacial landsystem. J. Maps 11, 415-431. doi: 10.1080/17445647.2014.919617

Evans, D. J. A., and Rea, B. R. (1999). Geomorphology and sedimentology of surging glaciers: a land-systems approach. Ann. Glaciol. 28, 75-82. doi: 10.3189/ 172756499781821823

Evans, D. J. A., Roberts, D. H., Bateman, M. D., Medialdea, A., Ely, J., Moreton, S. G., et al. (2018). Sedimentation during marine isotope stage 3 at the eastern margins of the Glacial Lake Humber basin, England. J. Quat. Sci. 33, 1-21. doi: 10.1002 /jqs.3066

Evans, D. J. A., Young, N. J. P., and Cofaigh, C. O. (2014). Glacial geomorphology of terrestrial-terminating fast flow lobes/ice stream margins in the southwest Laurentide Ice Sheet. Geomorphology 204, 86-113. doi: 10.1016/j.geomorph. 2013.07.031 
Eyles, N., Boyce, J. I., and Barendregt, R. W. (1999). Hummocky moraine: sedimentary record of stagnant Laurentide Ice Sheet lobes resting on soft beds. Sediment. Geol. 123, 163-174. doi: 10.1016/S0037-0738(98)00129-8

Eyles, N., and Clark, B. M. (1988). Storm-influenced deltas and ice scouring in a late Pleistocene glacial lake. Bull. Geol. Soc. Am. 100, 793-809. doi: 10.1130/ 0016-76061988100<0793:SIDAIS<2.3.CO;2

Gandy, N., Gregoire, L. J., Ely, J. C., Clark, C. D., Hodgson, D. M., Lee, V., et al. (2018). Marine Ice sheet instability and ice shelf buttressing influenced deglaciation of the minch ice stream, Northwest Scotland. Cryosph. Discuss. 12, 3635-3651. doi: 10.5194/tc-2018-116

Greenwood, S. L., Clark, C. D., and Hughes, A. L. C. (2007). Formalising an inversion methodology for reconstructing ice-sheet retreat patterns from meltwater channels: application to the British Ice Sheet. J. Quat. Sci. 22, 637-645. doi: 10.1002/jqs.1083

Greenwood, S. L., Clason, C. C., Helanow, C., and Margold, M. (2016a). Theoretical, contemporary observational and palaeo-perspectives on ice sheet hydrology: processes and products. Earth Sci. Rev. 155, 1-27. doi: 10.1016/j. earscirev.2016.01.010

Greenwood, S. L., Clason, C. C., and Jakobsson, M. (2016b). Ice-flow and meltwater landform assemblages in the Gulf of Bothnia. Geol. Soc. Lond. Mem. 46, 321-324. doi: 10.1144/M46.163

Greenwood, S. L., Clason, C. C., Nyberg, J., Jakobsson, M., and Holmlund, P. (2017). The Bothnian Sea ice stream: early Holocene retreat dynamics of the south-central Fennoscandian Ice Sheet. Boreas 46, 346-362. doi: 10.1111/bor. 12217

Hall, A. M., and Bent, A. J. A. (1990). The limits of the last British ice sheet in northern Scotland and the adjacent shelf. Quat. Newsl. 61, 2-12.

Hermanowski, P., Piotrowski, J. A., and Szuman, I. (2019). An erosional origin for drumlins of NW Poland. Earth Surf. Process. Landforms 44:4630. doi: 10.1002/ esp. 4630

Hjelstuen, B. O., Sejrup, H. P., Valvik, E., and Becker, L. W. M. (2017). Evidence of an ice-dammed lake outburst in the North Sea during the last deglaciation. Mar. Geol. 402, 118-130. doi: 10.1016/j.margeo.2017.11.021

Hodgson, D. M., Bernhardt, A., Clare, M. A., Da Silva, A.-C., Fosdick, J. C., Mauz, B., et al. (2018). Grand challenges (and Great Opportunities) in sedimentology, stratigraphy, and diagenesis research. Front. Earth Sci. 6:173. doi: 10.3389/feart. 2018.00173

Hogan, K. A., Cofaigh, ÓC., Jennings, A. E., Dowdeswell, J. A., and Hiemstra, J. F. (2016). Deglaciation of a major palaeo-ice stream in Disko Trough, West Greenland. Quat. Sci. Rev. 147, 5-26. doi: 10.1016/j.quascirev.2016.01.018

Hubbard, A., Bradwell, T., Golledge, N., Hall, A., Patton, H., Sugden, D., et al. (2009). Dynamic cycles, ice streams and their impact on the extent, chronology and deglaciation of the British-Irish ice sheet. Quat. Sci. Rev. 28, 758-776. doi: 10.1016/j.quascirev.2008.12.026

Hughes, A. L. C., Clark, C. D., and Jordan, C. J. (2010). Subglacial bedforms of the last British Ice Sheet. J. Maps 6, 543-563. doi: 10.4113/jom.2010.1111

Hughes, A. L. C., Gyllencreutz, R., Lohne, ØS., Mangerud, J., and Svendsen, J. I. (2016). The last Eurasian ice sheets - a chronological database and time-slice reconstruction, DATED-1. Boreas 45, 1-45. doi: 10.1111/bor. 12142

Hurter, S., and Haenel, R. (2002). Heat-Flow Density in Atlas of Geothermal Resources in Europe. Luxemburg: Office for Official Publications of the European Communities, 611-612.

Hurtig, E. (1995). Temperature and heat-flow density along European transcontinental profiles. Tectonophysics 244, 75-83. doi: 10.1016/00401951(94)00218-X

IPCC, (2013). IPCC Fifth Assessment Report. Geneva: IPCC.

Jakobsson, M., Andreassen, K., Bjarnadóttir, L. R., Dove, D., Dowdeswell, J. A., England, J. H., et al. (2014). Arctic ocean glacial history. Quat. Sci. Rev. 92, 40-67. doi: 10.1016/j.quascirev.2013.07.033

Jamieson, S. S. R., Stokes, C. R., Livingstone, S. J., Vieli, A., Cofaigh, C., Hillenbrand, C. D., et al. (2016). Subglacial processes on an Antarctic ice stream bed. 2: can modelled ice dynamics explain the morphology of mega-scale glacial lineations? J. Glaciol. 62, 285-298. doi: 10.1017/jog.2016.19

Jansen, J. H. F., Van Weering, T. C., and Eisma, D. (1979). "Late quaternary sedimentation in the North Sea," in The Quaternary History of the North Sea, eds E. Oele, R. T. E. Schiittenhelm, and A. J. Wiggers, (Uppsala: University of Uppsala), 175-187.
Kallehave, D., Byrne, B. W., LeBlanc Thilsted, C., and Mikkelsen, K. K. (2015). Optimization of monopiles for offshore wind turbines. Philos. Trans. R. Soc. A Math. Phys. Eng. Sci. 373:20140100. doi: 10.1098/rsta.2014.0100

Lamb, R. M., Huuse, M., and Stewart, M. A. (2016). Early quaternary sedimentary processes and palaeoenvironments in the central North Sea. J. Quat. Sci. 32, 127-144. doi: 10.1002/jqs.2894

Larsen, E., Fredin, O., Lyså, A., Amantov, A., Fjeldskaar, W., and Ottesen, D. (2016). Causes of time-transgressive glacial maxima positions of the last Scandinavian Ice Sheet. Nor. Geol. Tidsskr. 96, 1-12. doi: 10.17850/njg96-2-06

Lesny, K., and Wiemann, J. (2005). "Design aspects of monopiles in German offshore wind farms," in Proceedings of the International Symposium on Frontiers in Offshore Geotechnics, (Perth), 383-389.

Linch, L. D., and van der Meer, J. J. M. (2015). Micromorphology of ice keel scour in pebbly sandy mud and fine-grained sands: Scarborough Bluffs, Ontario, Canada. Sedimentology 62, 110-129. doi: 10.1111/sed.12142

Linch, L. D., van der Meer, J. J. M., and Menzies, J. (2012). Micromorphology of iceberg scour in clays: glacial Lake Agassiz, Manitoba, Canada. Quat. Sci. Rev. 55, 125-144. doi: 10.1016/j.quascirev.2012.07.008

Livingstone, S. J., Ócofaigh, C., Evans, D. J. A., and Palmer, A. (2010). Sedimentary evidence for a major glacial oscillation and proglacial lake formation in the Solway Lowlands (Cumbria, UK) during Late Devensian deglaciation. Boreas 39, 505-527. doi: 10.1111/j.1502-3885.2010.00149.x

Lockhart, E. A., Scourse, J. D., Praeg, D., Van Landeghem, K. J. J., Mellett, C., Saher, M., et al. (2018). A stratigraphic investigation of the Celtic Sea megaridges based on seismic and core data from the Irish-UK sectors. Quat. Sci. Rev. 198, 156-170. doi: 10.1016/j.quascirev.2018.08.029

Long, D., Laban, C., Streif, H., Cameron, T. D. J., and Schüttenhelm, R. T. E. (1988). The sedimentary record of climatic variation in the southern North Sea. Philos. Trans. R. Soc. Lond. 318, 523-537. doi: 10.1098/rstb.1988.0022

Longva, O., and Bakkejord, K. J. (1990). Iceberg deformation and erosion in soft sediments, southeast Norway. Mar. Geol. 92, 87-104. doi: 10.1016/00253227(90)90028-I

Lyså, A., Jensen, M. A., Larsen, E., Fredin, O., and Demidov, I. N. (2011). Ice-distal landscape and sediment signatures evidencing damming and drainage of large pro-glacial lakes, northwest Russia. Boreas 40, 481-497. doi: 10.1111/j.15023885.2010.00197.x

Margold, M., Stokes, C. R., and Clark, C. D. (2015). Ice streams in the Laurentide Ice Sheet: identification, characteristics and comparison to modern ice sheets. Earth Sci. Rev. 143, 117-146. doi: 10.1016/j.earscirev.2015.01.011

Margold, M., Stokes, C. R., and Clark, C. D. (2018). Reconciling records of ice streaming and ice margin retreat to produce a palaeogeographic reconstruction of the deglaciation of the Laurentide Ice Sheet. Quat. Sci. Rev. 189, 1-30. doi: 10.1016/j.quascirev.2018.03.013

McCabe, A. M., and Eyles, N. (1988). Sedimentology of an ice-contact glaciomarine delta, Carey Valley, Northern Ireland. Sediment. Geol. 59, 1-14. doi: 10.1016/ 0037-0738(88)90097-8

Mitchum, R. M., Vail, P. R., and Sangree, J. B. (1977). "Seismic stratigraphy and global changes of sea level, Part six: stratigraphic interpretation of seismic reflection patterns in depositional sequences," in Seismic StratigraphyApplications to Hydrocarbon Exploration, ed. C. E. Payton, (Tulsa, OK: AAPG), 117-134. doi: 10.1038/272400a0

Murton, D. K., and Murton, J. B. (2012). Middle and Late Pleistocene glacial lakes of lowland Britain and the southern North Sea Basin. Quat. Int. 260, 115-142. doi: 10.1016/j.quaint.2011.07.034

Nedbalová, L., Nývlt, D., Kopáèek, J., Šobr, M., and Elster, J. (2013). Freshwater lakes of Ulu Peninsula, James Ross Island, north-east Antarctic Peninsula: origin, geomorphology and physical and chemical limnology. Antarct. Sci. 25, 358-372. doi: 10.1017/S0954102012000934

Patterson, C. J. (1997). Southern Laurentide ice lobes were created by ice streams: Des Moines Lobe in Minnesota, USA. Sediment. Geol. 111, 249-261. doi: 10. 1016/S0037-0738(97)00018-3

Patton, H., Hubbard, A., Andreassen, K., Winsborrow, M. C. M., and Stroeven, A. P. (2016). The build-up, configuration, and dynamical sensitivity of the Eurasian ice-sheet complex to Late Weichselian climatic and oceanic forcing. Quat. Sci. Rev. 153, 97-121. doi: 10.1016/j.quascirev.2016.10.009

Pearce, D. M., Ely, J. C., Barr, L. D., and Boston, C. M. (2017). "Glacier reconstruction," in Geomorphological Techniques, 1st Edn, ed. A. Goudie, (Abingdon: Routledge), 16. 
Peters, J. L., Benetti, S., Dunlop, P., Cofaigh, ÓC., Moreton, S. G., Wheeler, A. J., et al. (2016). Sedimentology and chronology of the advance and retreat of the last British-Irish Ice Sheet on the continental shelf west of Ireland. Quat. Sci. Rev. 140, 101-124. doi: 10.1016/j.quascirev.2016. 03.012

Peters, L. E., Anandakrishnan, S., Alley, R. B., and Smith, A. M. (2007). Extensive storage of basal meltwater in the onset region of a major West Antarctic ice stream. Geology 35, 251-254. doi: 10.1130/G23222A.1

Phillips, E., Cotterill, C., Johnson, K., Crombie, K., James, L., Carr, S., et al. (2018). Large-scale glacitectonic deformation in response to active ice sheet retreat across Dogger Bank (southern central North Sea) during the Last Glacial Maximum. Quat. Sci. Rev. 179, 24-47. doi: 10.1016/j.quascirev.2017.11.001

Phillips, E. R., Evans, D. J. A., Atkinson, N., and Kendall, A. (2017a). Structural architecture and glacitectonic evolution of the Mud Buttes cupola hill complex, southern Alberta. Canada Quat. Sci. Rev. 164, 110-139. doi: 10.1016/j. quascirev.2017.03.027

Phillips, E. R., Hodgson, D. M., and Emery, A. R. (2017b). The quaternary geology of the North Sea basin. J. Quat. Sci. 32, 117-126. doi: 10.1002/jqs.2932

Powell, R. D. (1984). Glacimarine processes and inductive lithofacies modelling of ice shelf and tidewater glacier sediments based on quaternary examples. Mar. Geol. 57, 1-52. doi: 10.1016/0025-3227(84)90194-4

Powell, R. D., and Alley, R. B. (1997). "Grounding-line systems: processes, glaciological inferences and the stratigraphic record," in Geology and Seismic Stratigraphy of the Antarctic Margin, eds A. K. Cooper, P. F. Barker, G. Brancolini, (Hoboken, NJ: Wiley) 2, 169-187. doi: 10.1029/ar071p0169

Punkari, M. (1995). Glacial flow systems in the zone of confluence between the Scandinavian and Novaja Zemlya Ice Sheets. Quat. Sci. Rev. 14, 589-603. doi: 10.1016/0277-3791(95)00026-L

Punkari, M. (1997a). Glacial and glaciofluvial deposits in the interlobate areas of the Scandinavian ice sheet. Quat. Sci. Rev. 16, 741-753. doi: 10.1016/S02773791(97)00020-6

Punkari, M. (1997b). Subglacial processes of the Scandinavian ice sheet in Fennoscandia inferred from flow-parallel features and lithostratigraphy. Sediment. Geol. 111, 263-283. doi: 10.1016/S0037-0738(97)00019-5

Roberts, D. H., Evans, D. J. A., Callard, S. L., Clark, C. D., Bateman, M. D., Medialdea, A., et al. (2018). Ice marginal dynamics of the last British-Irish Ice Sheet in the southern North Sea: ice limits, timing and the influence of the Dogger Bank. Quat. Sci. Rev. 198, 181-207. doi: 10.1016/j.quascirev.2018. 08.010

Röthlisberger, H. (1972). Water pressure in intra- and subglacial channels. J. Glaciol. 11, 177-203. doi: 10.3189/S0022143000022188

Scourse, J., Saher, M., Van Landeghem, K. J. J., Lockhart, E. A., Purcell, C., Callard, S. L., et al. (2019). Advance and retreat of the marine-terminating Irish Sea Ice Stream into the Celtic Sea during the last glacial: timing and maximum extent. Mar. Geol. 412, 53-68. doi: 10.1016/j.margeo.2019.03.003

Sejrup, H. P., Aarseth, I., Ellingsen, K. L., Reither, E., Jansen, E., Lovlie, R., et al. (1987). Quaternary stratigraphy of the Fladen area, central North Sea: a multidisciplinary study. J. Quat. Sci. 2, 35-58. doi: 10.1002/jqs.3390020105

Sejrup, H. P., Clark, C. D., and Hjelstuen, B. O. (2016). Rapid ice sheet retreat triggered by ice stream debuttressing: evidence from the North Sea. Geology 44, 355-358. doi: 10.1130/G37652.1

Sejrup, H. P., Hjelstuen, B. O., Dahlgren, K. I. T., Haflidason, H., Kuijpers, A., Nygård, A., et al. (2005). Pleistocene glacial history of the NW European continental margin. Mar. Pet. Geol. 22, 1111-1129. doi: 10.1016/j.marpetgeo. 2004.09.007

Sejrup, H. P., Hjelstuen, B. O., Nygård, A., Haflidason, H., and Mardal, I. (2015). Late Devensian ice-marginal features in the central North Sea - processes and chronology. Boreas 44, 1-13. doi: 10.1111/bor.12090

Sejrup, H. P., Larsen, E., Landvik, J., King, E. L., Haflidason, H., and Nesje, A. (2000). Quaternary glaciations in southern Fennoscandia: evidence from southwestern Norway and the northern North Sea region. Quat. Sci. Rev. 19, 667-685. doi: 10.1016/S0277-3791(99)00016-5

Smedley, R. K., Chiverrell, R. C., Ballantyne, C. K., Burke, M. J., Clark, C. D., Duller, G. A. T., et al. (2017). Internal dynamics condition centennial-scale oscillations in marine-based ice-stream retreat. Geology 45, 787-790. doi: 10.1130/ G38991.1

Smith, N. D., and Ashley, G. (1985). "Proglacial Lacustrine environment," in Glacial Sedimentary Environments, eds G. M. Ashley, J. Shaw, and N. D. Smith, (Tulsa,
OK: Society of Economic Paleontologists and Mineralogists), 135-216. doi: 10.2110/scn.85.02.0135

Spagnolo, M., Clark, C. D., Ely, J. C., Stokes, C. R., Anderson, J. B., Andreassen, K., et al. (2014). Size, shape and spatial arrangement of mega-scale glacial lineations from a large and diverse dataset. Earth Surf. Process. Landforms 39, 1432-1448. doi: 10.1002/esp.3532

Stearns, L. A., and van der Veen, C. J. (2018). Friction at the bed does not control fast glacier flow. Science 2217:eaat2217. doi: 10.1126/science.aat 2217

Stewart, M. A., Lonergan, L., and Hampson, G. (2013). 3D seismic analysis of buried tunnel valleys in the central North Sea: morphology, cross-cutting generations and glacial history. Quat. Sci. Rev. 72, 1-17. doi: 10.1016/j. quascirev.2013.03.016

Stoker, M. S., Balson, P. S., Long, D., and Tappin, D. R. (2011). An Overview of the Lithostratigraphical Framework for the Quaternary Deposits on the United Kingdom Continental Shelf. Nottingham: British Geological Survey, 48.

Stokes, C. R. (2018). Geomorphology under ice streams: moving from form to process. Earth Surf. Process. Landforms 43, 85-123. doi: 10.1002/esp. 4259

Stokes, C. R., and Clark, C. D. (1999). Geomorphological criteria for identifying Pleistocene ice streams. Ann. Glaciol. 28, 67-74. doi: 10.3189/ 172756499781821625

Stokes, C. R., and Clark, C. D. (2001). Palaeo-ice streams. Quat. Sci. Rev. 20, 1437-1457. doi: 10.1016/S0277-3791(01)00003-8

Stokes, C. R., and Clark, C. D. (2003). The Dubawnt Lake palaeo-ice stream: evidence for dynamic ice sheet behaviour on the Canadian Shield and insights regarding the controls on ice-stream location and vigour. Boreas 32, 263-279. doi: 10.1111/j.1502-3885.2003.tb01442.x

Stokes, C. R., Tarasov, L., Blomdin, R., Cronin, T. M., Fisher, T. G., Gyllencreutz, R., et al. (2015). On the reconstruction of palaeo-ice sheets: recent advances and future challenges. Quat. Sci. Rev. 125, 15-49. doi: 10.1016/j.quascirev.2015. 07.016

Storrar, R. D., Stokes, C. R., and Evans, D. J. A. (2014a). Increased channelization of subglacial drainage during deglaciation of the laurentide ice sheet. Geology 42, 239-242. doi: 10.1130/G35092.1

Storrar, R. D., Stokes, C. R., and Evans, D. J. A. (2014b). Morphometry and pattern of a large sample $(>20,000)$ of Canadian eskers and implications for subglacial drainage beneath ice sheets. Quat. Sci. Rev. 105, 1-25. doi: 10.1016/j.quascirev. 2014.09.013

Streuff, K., Cofaigh, ÓC., Hogan, K., Jennings, A., Lloyd, J. M., Noormets, R., et al. (2017). Seafloor geomorphology and glacimarine sedimentation associated with fast-flowing ice sheet outlet glaciers in Disko Bay, West Greenland. Quat. Sci. Rev. 169, 206-230. doi: 10.1016/j.quascirev.2017.05.021

Sutherland, J. L., Carrivick, J. L., Shulmeister, J., Quincey, D. J., and James, W. H. M. (2019). Ice-contact proglacial lakes associated with the last glacial maximum across the Southern Alps, New Zealand. Quat. Sci. Rev. 213, 67-92. doi: 10.1016/ j.quascirev.2019.03.035

Szuman, I., Ewertowski, M., and Kasprzak, L. (2013). Thermo-mechanical facies representative of fast and slow flowing ice sheets: the Weichselian ice sheet, a central west Poland case study. Proc. Geol. Assoc. 124, 818-833. doi: 10.1016/j. pgeola.2012.09.003

Szuman, I., Kalita, J. Z., and Ewertowski, M. W. (2018). The impact of geothermal heat flux on the last Scandinavian ice sheet over W Poland and E Germany. Geogr. Ann. Ser. A Phys. Geogr. 100, 388-403. doi: 10.1080/04353676.2018. 1524711

Teller, J. T., Leverington, D. W., and Mann, J. D. (2002). Freshwater outbursts to the oceans from glacial Lake Agassiz and their role in climate change during the last deglaciation. Quat. Sci. Rev. 21, 879-887. doi: 10.1016/S0277-3791(01) 00145-7

Thomas, G. S. P., and Connell, R. J. (1985). Iceberg drop, dump, and grounding structures from Pleistocene Glacio-Lacustrine Sediments, Scotland. SEPM J. Sediment. Res. 55, 243-249. doi: 10.1306/212F8689-2B24-11D7$8648000102 \mathrm{C} 1865 \mathrm{D}$

Toucanne, S., Zaragosi, S., Bourillet, J.-F., Marieu, V., Cremer, M., Kageyama, M., et al. (2010). The first estimation of Fleuve Manche palaeoriver discharge during the last deglaciation: evidence for Fennoscandian ice sheet meltwater flow in the English Channel ca 20-18ka ago. Earth Planet. Sci. Lett. 290, 459-473. doi: 10.1016/j.epsl.2009.12.050 
Wahlgren, R. V. (1979). Ice-scour tracks in eastern Mackenzie Bay and north of Pullen Island, Beaufort Sea. Curr. Res. Part B Geol. Surv. Canada 7, 51-62.

Walder, J. S., and Fowler, A. (1994). Channelized subglacial drainage over a deformable bed. J. Glaciol. 40, 3-15. doi: 10.3189/S002214300000 3750

Wellner, J. S., Heroy, D. C., and Anderson, J. B. (2006). The death mask of the antarctic ice sheet: comparison of glacial geomorphic features across the continental shelf. Geomorphology 75, 157-171. doi: 10.1016/j.geomorph.2005. 05.015

Winsborrow, M. C. M., Clark, C. D., and Stokes, C. R. (2010). What controls the location of ice streams? Earth Sci. Rev. 103, 45-59. doi: 10.1016/j.earscirev.2010. 07.003

Woodworth-Lynas, C. M. T., and Guigné, J. Y. (1990). Iceberg scours in the geological record: examples from glacial Lake Agassiz. Geol. Soc. Lond. Spec. Publ. 53, 217-233. doi: 10.1144/GSL.SP.1990.053.01.12
Zolitschka, B. (2007). "Varved lake sediments," in Encyclopedia of Quaternary Science, ed. S. A. Elias, (Amsterdam: Elsevier), 3105-3114. doi: 10.1016/B0-44452747-8/00065-X

Conflict of Interest Statement: The authors declare that the research was conducted in the absence of any commercial or financial relationships that could be construed as a potential conflict of interest.

Copyright (c) 2019 Emery, Hodgson, Barlow, Carrivick, Cotterill and Phillips. This is an open-access article distributed under the terms of the Creative Commons Attribution License (CC BY). The use, distribution or reproduction in other forums is permitted, provided the original author(s) and the copyright owner(s) are credited and that the original publication in this journal is cited, in accordance with accepted academic practice. No use, distribution or reproduction is permitted which does not comply with these terms. 